\title{
Algumas Culturas Ceramistas, do Noroeste do Pantanal do Guaporé à Encosta e Altiplano Sudoeste do Chapadão dos Parecis. Origem, Difusão/Migração e Adaptação - do Noroeste da América do Sul ao Brasil
}

\author{
Eurico Theofilo Miller ${ }^{1}$
}

\begin{abstract}
Resumo
Nossa pesquisa por vínculos culturais materiais à Fase Bacabal, conduziu-nos até o Período Formativo Antigo da Costa do Equador: às Fases Valdívia e Machalilla. A Fase Valdívia que evoluiu no Óptimum Climáticum resultado de transgressão marinha, findou com ele devido a recessão marinha, que reduziu em muito o alimento dos brejos e mangues, mas não antes da Fase Machalilla se infiltrar e permanecer até 3.000 a.P. As datações Bacabal apontam para uma difusão/migração de Valdívia desde o litoral do Equador até o Pantanal do Guaporé-Brasil. Dos vínculos cerâmicos entre Valdívia e Bacabal o tipo Exciso em Zona Ampla, ou Diminuta, é a diferença entre Bacabal e Valdívia. Nas Fases Aguapé e GaleraBrasil, o tipo Exciso em Zona Ampla é uma das semelhanças entre a Bacabal e a Aguapé. O tipo Inciso em Linha Escalonada ocorre na Valdívia e na Galera. O tipo Inciso em Arco Raiado ocorre na Machalilla e na Galera. Com origem nas difusões, outras fases, surgiram ao longo do Chapadão dos Parecis. Os estímulos das difusões foram: (1) o Óptimum Climáticum, que avolumou a cadeia alimentar e a conseqüente pressão populacional; oposta à (2) regressão marinha com a semi-aridez severa, reduzindo a alimentação e a população, provocando entre os sobreviventes, dispersões e adaptações, por espaços com alimentos.
\end{abstract}

Palavras-chave: Arqueologia. Origem. Difusão. Evolução. Adaptação.

\begin{abstract}
Our search for material cultural links to the Bacabal Phase led us to the Early Formative Period of Coastal Ecuador: the Valdivia and Machalilla Phases. The Valdivia Phase which evolved to the Óptimum Climáticum as a result of marine transgression ended with it due to the marine recession, which greatly reduced food supply in swamps and mangroves, but not before Machalilla Phase infiltrated and lasted until 3.000 a.P. Bacabal radiocarbon datings point out to the diffusion of Valdivia from Ecuador coastline to the Pantanal do Guaporé-Brazil. Among the ceramic links between Valdívia and Bacabal the type Exciso em Zona Ampla, or Diminuta, is the difference between Bacabal and Valdivia. As to, Aguapé and Galera-Brazil: the type Exciso em Zona Ampla is one of the similarities between Bacabal and Aguapé. The type Inciso em Linha Escalonada occurs in Valdivia and in Galera; the type Inciso em Arco Raiado takes place in Machalilla and Galera. Originating
\end{abstract}

1 Doutor h. c. SAB Centro-Oeste. 
in the diffusion others from Ecuador/Colombia coastline, other phases appeared around Pantanal do Guaporé and along Chapadão dos Parecis. Diffusions were stimulated by: (1) Óptimum Climáticum, which increased the food chain and consequent population pressure, unlike (2) marine regression with severe semidryness, thus reducing food supply and the population, leading survivors to scatter in search for food sites and to adapt.

Keywords: Archaeology. Origin. Diffusion. Evolution. Adaptation.

\section{Retrospectiva Introdutória}

Há mais de 67 anos, então com 13 anos (1945) minha experiência contava com alguns cortes-testes executados em sítios arqueológicos no Nordeste do Rio Grande do Sul (Echeverria-Almeida 2012). Meu primeiro encontro memorizado deu-se numa fazenda de Carlos Steigleder em Rodeio BonitoTQR, ca. 500m (a.n.m.m.), provocado pelos meus tios Felipe e Valdomiro; aparentemente não dei importância, pois tinha então ao redor de 3-4 anos, mas deve ter-me impressionado. Nos anos seguintes, a atração foi crescendo e lá encontramos um grande complexo de pequenos sítios, com líticos lascados de pré-ceramistas, cunhado no Pronapa como Fase Camboatá; líticos e cerâmica da Fase Taquara (nessa altitude não raro com cerâmica de oleiras Tupiguaraní incorporadas ao povo Kaingang). Um grande "buraco de bugre", raro nessa altitude, servia de depósito para as ossadas do matadouro da fazenda. E foi assim que em 1960 ultrapassamos os 400 sítios, 101 sem cerâmica e 299 com cerâmica, cartografados no mapa que elaborei em 1952 e batizado de "Herman Von Ihering”. As coleções eram depositadas em caixas de sapato catalogadas, na "sapataria" do IPANORGS como pitorescamente era conhecido, envolvendo colaboradores escoteiros. E mais adiante (1962) aos alunos e professores do CIMOL onde lecionei. Revisitando a fazenda em 2004 encontramos a área dos sítios arqueológicos, desmatada e ocupada por um grande complexo budista.

Os livros sobre arqueologia, ciências da terra, ecologia e meio ambiente, etc. eram os da Biblioteca Pública e da UFRGS-Porto Alegre, que foram copiados e traduzidos; os cursos de extensão do gênero foram freqüentados, e resultou que "puseram lenha na fogueira". Em 1949 (17) meu salário como desenhista passou a me permitir a aquisição sem limite de livros principalmente de arqueólogos europeus.

\section{Do porquê deste trabalho}

O normal é a evolução, da "campânula", onde o começo ou princípio prossegue com o meio ou desenvolvimento e atinge a discussão e/ou conclusão. Tudo tem um começo cujo começo do começo é incipiente, um desenvolvimento e um final. Aplicando essa máxima à cerâmica dos 299 sítios oriundos de três culturas: a Guaraní agora Tradição Tupiguaraní; a Kaingang, depois Tradição Taquara e por fim Taquara-Itararé, agora nessa 
segunda proposta, como Subtradição Taquara da Tradição Taquara-Itararé. E Tradição Neobrasileira, Fase Monjolo no RS (Miller 1967), Fase Gama no D.F.,(Engea 1991a-c, 1992a-b) e Fase Jarú (Miller 1987b) cuja decoração plástica apresenta alguns traços assemelhados à cerâmicas afro-indígenas, de fases da Subtradição Taquara, e da Colonização Ibérica. As teorias e métodos da época usados individualmente ou por grupos de brasileiros formando escolas até ca. 1964, tiveram disponibilizado avanços na teoria e no método Ford (Ford 1957, UNIÓN Panamericana-OEA 1966, 1969), na terminologia (Chmiz 1966, 1969 e 1976) e na interpretação das seqüencias seriadas (Meggers y Evans 1970, 1985). Mais especificamente, sem o conhecimento ou uso do método Ford, que possibilita perceber variações e sutilezas ínfimas tipológicas, não era e continua não sendo possível captar e seriar variações quase imperceptíveis, provocadas por oscilações climáticas e suas conseqüências. Pior, se não eram mensuráveis sem o método continuam não sendo, se não existiam por falta do método, ou depreciado por desconhecimento continuam não existindo. Então não podiam ser levados em conta; então em todo o território nacional a cerâmica continuava mostrando-se sem o estágio insipiente do "princípio original" sem origem no Brasil ou de origem desconhecida ou de outras paragens; ou pior, não fazia parte do rol de interesses. No entanto já desde 1948, no Brasil, em parte em dependências do Museu Goeldi, o casal de arqueólogos Clifford Evans Jr. e Betty J. Meggers que aperfeiçoaram o método Ford, preparavam seus doutorados sobre culturas do Amapá e da Ilha do Marajó, cujo desenvolvimento resultou na obra monumental de: Meggers, Betty J.; Evans, Clifford. Archeological Investigations at The Mouth of The Amazon. Washington, D.C., Bur. Amer. Ethnol. Bull. 167, 1957.

Nela, na parte referente à Ilha de Marajó, é apresentada a Fase Ananatuba da Tradição Hachurada-Zonada assentada entre ca. 3.411 (TL) e 2.930 200 a. P. (SI-385) (Prous 1992). O tipo de decoração Hachurado Zonado é apresentado como atributo da Fase Valdívia na segunda obra monumental de: Meggers, Betty J.; Evans, Clifford \& Estrada, Emilio. 1965. Early Formative Period Of Coastal Ecuador: The Valdivia And Machalilla Phases. Washington, D.C., Smithsonian Contributions To Anthropology, V.1, 234p. Il.

Esta, resultante de pesquisas conjuntas, entre Emílio Estrada do Equador, Betty J. Meggers e Clifford Evans da Smithsonian Institution, desde 1954 (Echeveria-Almeida, 2012; Muñoz, 2012).

\section{A busca pela origem e rotas de difusões, das cerâmicas, da agricultura e aldeamentos; dos Formativos Antigos de Valdívia e Puerto Hormiga}

O espaço físico desde a Costa Pacífica do Equador, com a cerâmica da

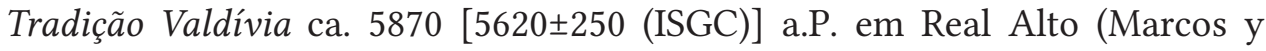


Obelic 1998) à Costa Caribenha da Colômbia, com a cerâmica da Tradição Puerto Hormiga ca. 6130 (5700 \pm 430$)$ a.P. em San Jacinto 1 [(Oyuela-Caycedo y Bonzani (2005); Reichel-Dolmatoff (1965)], é considerado como a origem do Período Formativo Antigo, desde onde se originaram e difundiram as cerâmicas que se dispersaram pelo Continente Pan-americano desde ao menos 6130 anos a.P. Na verdade a Tradição Valdívia aportou, com as etapas Insipiente e Formativo prontas, evoluídas, com seus atributos muito bem elaborados nos assentamentos. De onde chegou? Quando? Por quê? Como? As pesquisas sobre os indícios levaram à Ilha japonesa de Kyushu com a cerâmica fomon Médio cujo estágio Incipiente, aconteceu desde ca. 14.000 - 13.000 anos atrás. Em ca. 6.300 a.P. Fomon Médio estava florescendo, quando a Ilha de Kyushu foi impactada pela erupção de proporções catastrófica do vulcão Kikai que a tornou inabitável por séculos, levando a população às migrações, que no litoral do Equador deu origem ao Período Formativo Antigo com a Tradição Valdívia, com as etapas Incipiente e Formativo plenamente desenvolvido quando ainda alóctone, e assim aportaram na costa ocidental americana (Machida y Arai 1983; Meggers, 2008). Estes foram os acontecimentos, pelo menos em parte, que deram condições de surgir no litoral pelo menos do Equador à cerâmica fomon onde foi cunhada como Tradição Valdívia. Quanto à cerâmica da Tradição Puerto Hormiga, em San Jacinto 1 algo mais antiga, sobre outras cerâmicas pelo litoral Caribenho da Colômbia para oriente, antes de traçar maiores conjecturas, penso que ainda falta o apoio de mais escavações extensas e intensas, datações e análises focando a decoração a serem apresentadas por publicações profundamente informativas e ilustradas como a de Meggers, Evans e Estrada (1965), e sem o que, não teremos as referências qualitativas e quantitativas suficientes. A Tradição Valdívia representa a cultura alóctone de fomon Médio plenamente desenvolvida na época de sua migração para a América Ocidental, sendo o que a distingue dos demais formativos antigos autóctones já reconhecidos.

A economia na divulgação econômica não ajuda, na verdade pode ser até antieconômica porque não atinge o objetivo, antes prejudica a informação principalmente visual. Publicações recheadas com mais imagens fotográficas à cores e detalhadas, em quantidade, além de desenhos, além dos textos, é a linguagem universal que todos entendemos. Lembremos, apesar de alguns discordarem, uma ótima imagem vale por "mil" palavras; a descrição de um animal desconhecido, passada para várias pessoas, para que o desenhassem, resultou em animais diferentes, que nunca existiram.

Como dito, informações que realmente informem, com base em amostragens não selecionadas às centenas, aos milhares, vão dar muito trabalho, mas será um trabalho com informações mais próximas da realidade. É desse tipo de apoio que a conclusão de todos nós precisa; levar as inferências para mais além do especulativo. Preocupam-me os trabalhos pouco documentados 
frente aos empreendimentos, ao PAC, etc. ex.: em 2009 estive frente à frente com o Sambaqui Taperinha, que ostentava então parcos $3 \mathrm{~m}$ de altura sobre um corpo conicóide cuja base dispersa "exageradamente" ainda teria $250 \mathrm{~m}^{2}$ (após aguardar desde 1992, autorização que sequer nos foi respondida pelo IBPCRio, para executar projeto de pesquisa arqueológica com Celso Perota da UFES no Baixo Rio Amazonas [Miller 1992] ). Na época minha intenção, por convite meu à Ana C. Roosevelt, fora um corte-teste $5 \times 5 \mathrm{~m}$ (pela pouca cerâmica) até $2 \mathrm{~m}$ abaixo do sambaqui, em conjunto, ela e eu, cujo resultado fosse qual fosse, seria aceito incondicionalmente por Betty J. Meggers (parece que o convite, em mãos desde Brasília, não lhe chegou). Essa pesquisa ainda necessária e viável é fundamental para determinar a cultura material daqueles sambaquianos: eram de início pré-ceramistas seguidos por ceramistas? Ou somente ceramistas? As informações ilustradas fotograficamente sobre o material arqueológico que Roosevelt extraiu não são tantas como gostaríamos que cientificamente fossem. Essa superficialidade se repete noutros sítios congêneres, por outros autores (inclusive os meus), como na Ponta do Jauarí (afora o trabalho de Peter P. Hilbert 1968) sejam marinhos ou dulce-aqüícolas, cuja estimativa cronologia, ao redor de 4200 a.P., o coloca no evento da semi-aridez severa, sobressaindo ao rio Amazonas. Como não há preservação há a necessidade da recuperação de mais evidências cerâmicas (e outras), antes da perda total dos testemunhos que se encontram, em Taperinha e Jauarí antes que se tornem apenas mitos. E, a continuidade dos importantíssimos estudos físicos das marés (Goulding, Barthem e Ferreira 2003) e das "paleomarés", que atingiram o rio Amazonas e região do Sambaquí da Taperinha ao longo e no auge do Óptimum Climáticum Ca. 7.500 - 4.300 a.P.; e do "Péssimo Climático" ca. 4300 - 4.050 a.P., evento caracterizado e representado pelo semi-árido entre as Fases Umbu e Itapuí pré-cerâmicas em abrigo sob rocha, e Fases Sinimbu e Bacabal pré-cerâmica e cerâmica em sambaquis (Miller 1969, 2009); constatamos de 1974 para cá a presença em rios da Amazônia, com destaque para o Madeira, de petroglifos que permanecem mergulhados mesmo nas secas mais severas, sugerindo que teriam sido elaborados por ocasião do péssimo climático. Betty Meggers e Ruth Shady nos informaram que esse mesmo evento, o "Péssimo Climático" seria o responsável também pelas falências das culturas Valdívia e Caral. Quer nos parecer que o "Péssimo Climático" teria sido um semiárido ao menos de proporções hemisférica.

Pesquisas e datações, em todas as direções, mesmo com amostragens que na maioria não ultrapassam algumas dezenas, centenas de fragmentos, revelaram o quanto, o quando, o para onde, o por onde e o porquê ocorreram difusões de culturas cerâmicas portadoras de vínculos com mais ou menos semelhanças nos atributos da Tradição Valdivia, da Tradição Puerto Hormiga; depois Machalilla e Chorrera desde Ocós de Guatemala (Coe 1960), etc. As inovações chegando ao norte até Mogolon e stallings Island; para o sul até Tafi e Fase 
Guatambu da Subtradição Taquara; e para o leste até Ananatuba. Mina e Una, estando a mais antiga, segundo Roosevelt $(1995,1996)$ no sambaqui Taperinha de água doce. As cerâmicas difundidas seus nomes, rotas e assentamentos foram cartografadas por Meggers (1970, p.10-11, 1972 e 1979, p. 54-61), e neste trabalho com meus acréscimos de outras culturas em nota prévia, por detalhar noutro trabalho (Fig. 18).

Partindo desses resultados de difusão e desenvolvimento cultural com base no Formativo Antigo com as Tradições Valdívia, Puerto Hormiga ensaiamos o encontro da origem e da difusão da Fase Bacabal com ca. 4.055 à 700 a.P. no Pantanal do Guaporé, Rondônia (Fig. 17), que revelou ter uma expressiva parcela de ligações temáticas com técnicas e motivos decorativos incisos, raspados, semelhantes e evoluídos da Tradição Valdivia (Miller 2009a, Figs. 2-5); bem como formas de vasilhame com a porção superior em perfil horizontal ovalado, em "forma de bote" (Raymond, Oyuela-Caycedo and Carmichael, 1998, OyuelaCaycedo and Bonzani 2005), uma das formas do sítio Puerto Chaco, próximo a Puerto Hormiga, Colômbia, raríssima mas presente em Valdívia-Equador. Em Bacabal-Brasil o percentual da forma é crescente da meia altura para o topo da seriação Bacabal (Miller 2009b, Fig. 8); os recipientes de planta esferóide até meia altura, assumem daí para a borda a forma elíptica alongada, sugerindo a forma de "bote"; coincide com a introdução da mandioca e o princípio do aldeamento.

Foram localizadas várias outras cerâmicas, que tenho pesquisado desde 1974 ao longo dos rios Madeira, Mamoré, Guaporé, encosta superior ocidental do Chapadão dos Parecis e sobre o altiplano, ao longo das nascentes de afluentes do rio Juruena (Fig. 1). Essas cerâmicas apresentam técnicas e motivos decorativos de quatro culturas reunidas na costa do Equador: Tradição Valdívia, (Estrada 1961, Meggers, Evans and Estrada 1965), Machalilla originária das terras altas (Meggers and Evans 1962) Chorrera, migrada da Guatemala (Coe 1960) e Jambeli (Estrada, Meggers and Evans 1964), através de adaptações de alguns atributos resultando em tipos com técnicas e motivos de decoração surpreendentes das quais nos ocuparemos, à nível de nota prévia, da decoração de duas: da Fase Aguapé e da Fase Galera, neste trabalho.

\section{Do conteúdo dos sambaquis gerados pelo nativo}

Normalmente todo sambaqui é pré-cerâmico ou tem uma etapa primeira pré-cerâmica; e a seguinte, acima, é ceramista. Os sambaquis com uma etapa pré-ceramista, discreta ou destacada, é o que predomina em ambiente fluviolacustre em água doce no Pantanal do Guaporé, Rondônia, com précerâmico discreto ou pouco diferenciado sotoposto a uma ocupação ceramista também discreta, e dispersa. Nestes, todo o cuidado é pouco porque toda experiência é pouca perante desacertos quanto à posição original da cultura e 
da amostra para, exames, datação e outros fins. Abrindo um entre parêntesis: num assentamento de coletores, pescadores e caçadores, sobre solo não consolidado, a disposição das atividades e seus restos, será desfeita, misturada, irreconhecível pelo acampamento sazonal seguinte, ou antes pelo vento, seca e/ou chuva, por animais e insetos de galeria (tatu, ratos, formigas, larvas de coleópteros e lepidópteros; a saúva, para seu ninho subterrâneo, remove e sobrepõe ao solo dezenas de m3 onde, pela ação do intemperismo aquirem a forma progressivamente abaulada. A estratigrafia quando protegida dos fenômenos naturais, registra todas essas atividades, inclusive a humana. Já num assentamento à céu aberto tipo aldeia de agricultores pré-cerâmicos da Fase Massangana à cerâmicos da Fase Urucurí da Tradição Famari (Miller, 1992, 2009b) (Subtradição Famari da Tradição Tupiarikém; em re-edição aguardando recursos), pela atividade bem mais intensa, irá gerar espontânea e conseqüentemente a terra preta, segundo seus padrões de semi-sedentarismo e recursos de subsistência, demografia, dispersão e reocupação, ocorre o oposto. Ai o volume de terra preta gerada, se torna um só estrato cultural, sem evidência clara de estratigrafia; exceção para o Proto-Tupiguaraní (Miller 2009b). Se ocupado por mais de uma cultura de ceramistas, resultará mais ou menos misturada contaminando para mais ou para menos as amostras para análises e datações, e as amostras materiais culturais, para caracterização de cada cultura presente no sítio, no espaço e no tempo, formará um quadro que as vezes nunca existiu.

Esse processo também está presente nos sambaquis, muitos deles com sobreposição de culturas, em todos os sentidos, como descrito acima, uma pode contaminar à outra, ou umas às outras. Quando a sobreposição de sítios envolve uma cultura ceramista, exemplificando com um caso real: no assentamento em sambaqui RO-PN-8: Monte Castelo, no Pantanal do Guaporé, Rondônia (Miller 2009a): a Fase Bacabal ceramista ca. 4055 à 700 a.P.; que está sobre a Fase Sinimbu pré-ceramista entre 7100 à 4350 a.P.; que está sobre a Fase Cupim pré-ceramista, transição seco/frio com úmido/quente (Optimum Climaticum incipiente) ca. 7400 a 8400 a.P. A subsistência do bando ainda não deixara de ser de um coletor de flora e fauna de ambiente em savana semi-árida, e a alternância climática o torna anual e ciclicamente, um coletor sazonal de flora e fauna em ambiente ora alagado ora seco a semi-árido (Miller 2009a). Com base no corte-4, nesse sítio-sambaqui temos duas sobreposições culturais: de acima da cultura Cupim, a base da ocupação Sinimbu que se estende ca. 4,7 m acima até a base do extrato-Guia Sinimbu - Bacabal, estéril, com ca. 10 - 30 cm.; sobre esse estrato-Guia assenta a base da ocupação da Fase Bacabal que se estende ca. 2,0 m acima até o topo do sambaqui. Os espaços entre as duas sobreposições é constituído por estratos naturais que foram sendo misturados com as bases e topos das fases, pelas reocupações. Entre Cupim e Sinimbu ocorreu mistura de solos com restos de alimentação bem diferenciável, mas 
não quanto às poucas lascas líticas, distinguíveis pelo solo original aderido. Os sedimentos Sinimbu e Bacabal são formados pelas conchas das mesmas espécies de gastrópodes fluviolacustres mais os sedimentos arenosos dos lagos. O estrato natural que está preservado nos solo lacustre areno-humoso à turfoso, entre Sinimbu e Bacabal, foi originado por um episódio semi-árido severo, entre 4.350 e 4100 a.P. cunhado como Estrato Guia Sinimbu - Bacabal, atingido pela mistura dos sedimentos culturais de transição das duas culturas até $30 \mathrm{~cm}$ de espessura. Penetrando a camada pré-cerâmica Sinimbu. Ainda percebe-se nos perfis, tênues traços de esteios da Fase Bacabal e fragmentos cerâmicos até $80 \mathrm{~cm}$ nos sedimentos pré-cerâmicos da Fase Sinimbu e fragmentos de cerâmica intrusivos, mas sem indícios do deslocamento, mas identificáveis como fora de contexto. A avaliação do quanto esses fragmentos cerâmicos estavam deslocados no tempo, para mais, (para dentro da camada pré-cerâmica Sinimbu) chegou-se a até 1.133 anos, ou seja de 4.050 anos a.P. a Fase Bacabal seria estimada em ca. 5.183 anos a.P. E parte do sambaqui préceramista aparentemente faria parte do sambaqui ceramista (Miller 2009a, Fig. 2).

Pesquiso sambaquis desde 1950 na orla marinha do Rio Grande do Sul, mas foi com o Pronapa (Miller 1967) que as pesquisas tiveram os recursos necessários para seu avanço junto ao mar, mangue e em canais de intercomunicação marinha e lagos de água doce. Os grandes banhadais do interior do Rio Grande do Sul ao contrário de Rondônia no lugar de sambaquis ostentam grandes conjuntos de aterros, os maiores com base elíptica $86 \times 12$ com altura de $7 \mathrm{~m}$ acima das águas, em forma assimétrica: lados em declive acentuado envolvendo uma extensa rampa suave; que saibamos nunca foram escavados e, para quem tentar, prepare-se para um solo tipo concreto no topo da rampa. Em Rondônia no centro Sul-americano, pesquisei desde 1978 (Miller 1978a,b, 1980, 1983b, 1986a,b) sambaquis fluviolacustres no Pantanal do Guaporé (Miller 2009a). Tanto no Rio Grande do Sul com sambaquis marinhos como em Rondônia com sambaquis, fluviolacustres, todos os sambaquis são o resultado do assentamento inicial de pré-ceramistas (sem ponta de projétil líticas, mas com as pontas ósseas mais antigas na Fase Cupim e Sinimbu); no Rio Grande do Sul, com ocupação final pela Tradição Humaitá, Fase Camboatá, Subtradição Taquara Fases Taquara e Guatambu (Miller, 1967 e 1971), e pela Tradição Tupiguaraní Fases Maquiné e Paranhana (Miller 1967); no último milênio e meio. Os patamares areno argilosos litorâneos, poucas centenas de metros do mar, eram ocupados pela Tradição Umbu Fases Umbu e Itapuí (Miller 1967, 1974a). Os sambaquis do Pantanal do Guaporé, resultado inicial dos préceramistas da Fase Sinimbu, após 250 anos de semiaridez, são reocupados pelos ceramistas da Fase Bacabal durante 3.300 anos contínuos, gerando uma ocupação com $200 \mathrm{~cm}$ de espessura com muita cerâmica que lembra a Tradição Valdívia e a Tradição Puerto Hormiga Fase Puerto Chacho com cerâmica em 
forma de bote. Não conheço sambaqui resultante somente do assentamento de ceramistas, se houver, é uma experiência que me faz falta.

Roosevelt (1995), Roosevelt et al. $(1991,1996)$ apresenta algumas datações da cerâmica da Caverna da Pedra Pintada, e do Sambaqui da Taperinha com 383 cacos cerâmicos, mas só três foram divulgados primeiramente em forma de desenho e depois em foto, entre 7080+/-90 a 6300+/-90 a. P. sendo o único sítio a ter datas bem mais antigas que as obtidas para as demais tradições formativas como San Jacinto 1 da Costa Caribenha. No entanto, essa cerâmica Taperinha apresentada, não é coerente com as datações antigas apresentadas, lembram e assemelham-se contraditoriamente à cerâmica Barlovento, entre $3500+/-100$ e $2800+/-80$ a.P. da costa norte colombiana (Meggers 1997), e com a cerâmica Manacapuru, com 1425+/-58 a.P. (Hilbert 1968; Meggers 1997), bem mais recentes. Entre as técnicas e os motivos da decoração e as datações, a linguagem das imagens fotográficas fala mais alto que as datações, portanto a questão permanece em aberto. "The ceramic sequence on the Caribbean coast of Colombia is the best documented in South America as a result of detailed investigations and publications by Geraldo Reichel-Dolmatoff (1985) and Carlos Angulo Valdez (1981) and the chronology of change in decoration is well defined. (...)" (Meggers 2010). E como a Tradição Valdívia equatoriana, com apoio em Real Alto, que possuem dezenas de sítios ancorando claramente suas posições cronológicas; com dezenas de milhares de fragmentos cerâmicos, e todo um rol diversificado e evoluído do material de expediente; publicações bem ilustradas que falam por si com excelência, na obra. no entanto, não suporta as datações apresentadas; lembram e assemelham-se contraditoriamente à cerâmica Barlovento, entre 3500 e 2800 a.P. da costa norte colombiana (Meggers 1997), e com a cerâmica Manacapuru (Hilbert 1968; Meggers 1997) Entre as técnicas e os motivos da decoração e as datações, a linguagem das imagens fotográficas fala mais alto, portanto a questão permanece em aberto.

Nessa relação contraditória entre imagem fotográfica e datações há um flagrante desacerto; e pende a favor da imagem fotográfica semelhante a cerâmica Barlovento e Manacapuru com datas a elas creditadas. Creditar as datas antigas de Taperinha a estas cerâmicas Barlovento e Manacapuru é uma flagrante comprovação de que elas estavam infiltradas em meio précerâmico que explica essa contradição. Até que uma equipe seja designada para comprovar em campo a existência ou não de ocupação pré-cerâmica no sambaqui da taperinha, a questão da validade das datações para o material cerâmico fica em aberto. É interessante que as datas iniciais do sambaqui da taperinha ceramista $7080+/-90$ a.P. e do sambaqui Monte Castelo pré-ceramista e ceramista $7010+/-80$ a.P. sejam muito próximas.

Em: Meggers, Betty J.; Evans, Clifford \& Estrada, Emilio. 1965. Early Formative Period of Coastal Ecuador: the Valdivia and Machalilla Phases. Washington, D.C., Smithsonian Contributions to Anthropology, V.1, 234p. Il. 
É detalhado científica, técnica e tipológicamente, toda a diversidade cultural, com analogias comparativas, ilustrando a mesma cultura: como fomon no Japão e como uma variante, Valdívia no Equador. Uma idéia consistente da origem de Valdívia com 5.800 anos no Equador após 7,200 anos no Japão, e 14.000-13.000 anos desde o fomon incipiente que não deixa dúvidas quanto ao seu lugar e papel no cenário cultural cerâmico Panamericano; coexistindo e interagindo com outros complexos antigos autóctones que, devido sua semelhança com Barlovento na Colômbia e Manacapurú na Amazônia central, é fundamental comprovar se Taperinha tem ou não assentamento inicial pré-cerâmico; será estratégico como apoio à existência de outros sítios com resultados que apóiem complexos como o Formativo Antigo da Tradição Proto-Tupiguaraní apoiado por vários sítios entre 5.100 e 4.000 anos na Área do Alto Ji-Paraná-Rondônia com uma primeira publicação (Miller 2009b), apoiada pela lingüística Tupi (Rodrigues 1958, 1964, 1986, 1988, 2007 e 2010) e pela arqueologia preventiva (Scientia 2008; Cruz 2008; Zimpel Neto 2009; Miller 1987).

\section{Origem do Formativo Pacatuba/Massangana/Tupiarikém}

Da origem do Período Formativo Antigo da agricultura e aldeamentos de pré-ceramistas à ceramistas no Jamarí.Já em 5.300 a.P. macro-bandos compostos por pré-ceramistas coletores caçadores, evoluídos de uma horticultura insipiente, simultaneamente dominaram a agricultura da mandioca, a construção de aldeias e se tornaram semi-sedentários. É a interpretação da terra preta intensiva de longa duração dos sítios da cultura Massangana. Que se estendeu de 5280 a $2810(5210 \pm 70$ a $2750 \pm 60)$ a.P. Um período com 2460 anos. Massangana é a evolução da Fase Pacatuba pré-cerâmica como caçador coletor com horticultura incipiente. Pacatuba se estendeu de ca. $6.220(6,090 \pm 130)$ à

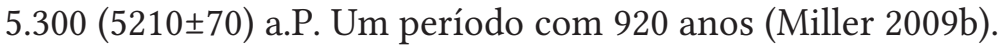

\section{Origem do Formativo Antigo da Tradição Proto-Tupiguaraní}

Da Tradição Tupiguaraní da Faixa Costeira (PRONAPA, 1968), ao centro de origem do Formativo Antigo da Tradição Proto-Tupiguaraní, na Área do Alto Ji-Paraná - desde o estágio insipiente final do "princípio original". Em 1969, foi reconhecido o vínculo etno-histórico e linguístico dos falantes Tupi-Guarani com a cerâmica arqueológica correlata da Faixa Costeira, a qual foi denominada de Tupiguarani (Brochado et. al. 1969; PRONAPA 1968, 1969, 1970). Desde 1958, a "terra natal" do Tronco Tupí foi proposta como tendo sido na mesopotâmia Guaporé-Madeira e Aripuanã (Rodrigues 1958a, 1964), por conter seis das suas dez famílias lingüísticas (Rodrigues, 1986). Em 1913 a Missão Rondon encontrou falantes de línguas Tupí-Guaraní (Kawahib) e suas malocas no alto Jí-Paraná-RO (Missão Rondon 2003). Desde 1974 temos estado in loco, testando teórica e empiricamente essa hipótese, com o PROPPA,1974-7/MT- 
RO, o PRONAPABA,1978-83/RO-AM, o GERO a Eletronorte e o CNEC. Além das cerâmicas mais diagnósticas com as decorações Corrugada Complicada e Pintada e de urnas funerárias tão antigas quanto a "terra natal”, há lá outros atributos do tipo Tupiguaraní. O mesmo vínculo entre dados arqueológicos, etno-históricos e linguísticos encontrado, na Faixa Costeira foi testado na "terra natal" do Proto-Tupí e do Proto-Tupí-Guaraní, tendo resultado na mesma correlação. A busca empírica pela "terra Natal” do tronco tupí chegou até ao seu miolo, através da correlação entre os dados da arqueologia de campo, datações $14 \mathrm{C}$, lingüística histórica e fontes etno-históricas.

A descoberta do centro de origem do Proto-Tupiguaraní, antecessor do Tupiguaraní, sob pesquisa centripeta no Sudoeste Amazônico, deu-se na Àrea do Alto Jí-Paraná tendo o sítio RO-JI-15: Urupá com 5.100 a.P. e outros entre 5000 e 4000 a.P. (Scientia 2008; Cruz 2008; Zimpel 2009) e de 4000 a 500 a.P. como apoio cronológico e demais atributos,foi apresentado no II Encontro Linguas e Culturas Tupí. UNB-DF, 2007 (Miller 2009b). Com base nos dados levantados, é possível calcular que o principio do insipiente "princípio original" esteja entre 5,5 e 6 mil anos atrás, e chegar lá exigirá a pesquisa de muitos sítios Proto-Tupiguaraní, probabilisticamente junto de águas rápidas na bacia do Alto Ji-Paraná. Com relação ao Formativo do Tupiguaraní penso que houve um bom e diversificado progresso através do estágio arqueológico evolutivo de origem e difusão porque os tipos Pintado e Corrugado do insipiente final do Proto-Tupiguaraní foram localizados junto ao Alto rio Ji-Paraná com falantes Kawahib, conclusões essas que nos ocuparam por 33 anos, de 1974 à 2009 (Miller 2009b), e continuam ocupando.

O intrigante é que no Formativo Antigo do Equador, na Tradição Valdívia, só ocorre o Corrugado Simples e o Pseudo Corrugado que lembra vagamente o Corrugado Complicado mal feito, mas não possui o Corrugado Complicado (Chmiz 1966:12; 1976:126-127) nem o Pintado (mono à tricolor), sobre superfície simples ou, sobre engobo branco e/ou vermelho que é o tipo principal do Proto-Tupiguaraní(Miller 1969: 33-54, Est.11-12) e do Tupiguaraní (Miller 1969: 33-54, Est.11-12) Esse contexto aponta o Alto Jí-Paraná como o berço do Período Formativo Antigo Independente do Proto-Tupiguarani. Com esse resultado, o que antes se pensava ser um fato, de que todas as tradições cerâmicas derivavam necessária e unicamente do Formativo Antigo Tradição Valdívia, já não tem sustentabilidade; e com o transcorrer das pesquisas outros centro formativos independentes surgirão, pois entre os grandes complexos cerâmicos ocorrem cerâmicas classificadas simplesmente como Tradições Regionais. O Proto-Tupiguaraní é uma cultura ceramista relativamente antiga, que progrediu com o Ótimo Climático e graças ao aquífero Parecis, sobreviveu à uma semi-aridez severa, alcançando ambientes ecologicamente menos desconfortáveis na Faixa Costeira Atlântica, a qual lhe propiciou sobrevivência sustentável. Outros detalhes em Miller (2009b). 


\section{Da Origem do Formativo Antigo da Tradição Policroma}

Na busca pelas origens e rotas de difusões da Tradição Polícroma e respectivas Subtradições. A descoberta da Subtradição fatuarana deu-se em RO-JP-01; Teotônio e RO-JP-03: Porto Seguro em 1978, nas cabeceiras da Cachoeira Teotonio (Miller 1978c, 1979a, 1980b, 1985a, 1985b, 1986c, 1992b), e o local, com um grande complexo de sítios-habitação e oficinas, logo foi considerado como o centro formativo tanto da Subtradição fatuarana como

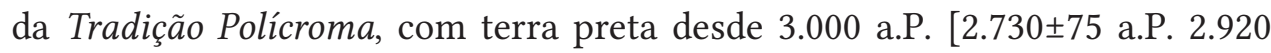
a.P. $=1950+970 \mathrm{BC}$ correção $930 \mathrm{BC}+1950=2.880$ a.P. $($ SI-3950) $]$ a.P. e seus atributos cerâmicos plenamente evoluídos (Fig. 6), sem o menor indício de cerâmica incipiente, (um paradoxo: quanto mais antiga mais elaborada, mais diversificada, não significando isso um princípio de decadência). Este complexo cultural retrata o rio Madeira em toda a sua extensão, rio Madeira abaixo e rio Madeira acima, ultrapassando a confluência do rio Beni e galgando as corredeiras de montante já no baixo Mamoré até a cidade de Guajará-Mirim, m.d. com o sítio polícromo RO-GM-10, também nas ilhas algumas também com arte rupestre e cemitérios. Nesse panorama a hipótese que atenta sugere a área de origem, a "terra natal", para além do Mamoré ecologicamente muito inferior ao Madeira. Especulativamente na bacia do alto Beni, ou do Madre de Dios nos contra-fortes andinos, cujos tributários mais extensos são de água-branca-andina. Em termos de subsistência estes são os que se aproximam do Rio Madeira, contudo em escala reduzida, suportando um episódio cultural incipiente até um princípio de evolução e desenvolvimento com população crescente cujos recursos ripícolas, aquáticos e hortícolas, em maior demanda, já não sustentavam aquela sociedade em crescimento e foi quando o rio Madeira, já conhecido, começou a ser ocupado com o resultado que a arqueologia está revelando. Mas as referências sobre o Beni não são animadoras quanto à indícios de policromia; se assim se confirmar, com os reservatórios das UHE's no rio Madeira, pouco haverá para pesquisar no alto Madeira, quanto à origem da Subtradição fatuarana e Tradição Polícroma.

A Subtradição fatuarana foi a cultura nativa que em melhores condições sobreviveu com sedimentos de solo vulcânico andino, rico em nutrientes canalizados para o Madeira pode assegurar uma sobrevivência sustentável, como foi por ao menos 3.000 anos contínuos. Os antigos polícromos devem ter abandonado o local de origem por já não suportar o desenvolvimento pós etapa insipiente ingressando na etapa evolutiva quando por motivos ecológicos tiveram que e conseguiram "descobrir o rio Madeira" para se tornarem na Subtradição fatuarana que encontramos, e pelo Amazonas e afluentes afora, dar origem às demais subtradições Fig. 6).

Os petróglifos do sítio RO-GM-02: Pederneiras-1 nunca totalmente à descoberto das águas sugerem que foram elaborados num período de semi- 
aridez severa, no "Péssimo Climaticum" entre 4.300 e 4.100 a.P.; a Subtradição fatuarana, um milênio após, se instalou e sobreviveu no Rio Madeira, numa faixa ecológica de conforto (Miller 1992b), pela água do degelo andino nas intensas estiagens do Madeira, até o impacto da presença ibérica.

A revisão em 1986 das coleções de campo efetuadas em 1980, estenderam a Tradição Polícroma até as porções inferiores dos seus formadores os rios Mamoré e Beni, como domínio da Subtradição fatuarana que também surge pronta em toda essa extensão, desde Ca. 3.000 anos a.P. Sendo o médio Mamoré acima e o Guaporé domínio de culturas outras que não a Tradição Polícroma (Miller 1980, 1983a, 1987c,d).

\section{Surge o PRONAPA, com o Método Ford-Meggers (1964)}

Com base nos princípios teóricos, metodológicos, terminológicos, etc., que o norteiam (Echeverria-Almeida 2012) tudo se torna perceptível e mensurável pelas análises seriadas quantitativas, em "complexos", "tradições", "subtradições", "fases" e "subfases" adotadas desde 1964. A tipologia e a quantificação através do tempo e do espaço, e considerações ecológicas e ambiental, com mudanças climáticas, sejam favoráveis ou danosas, já são perceptíveis na seqüências seriadas. Os nomes das culturas e sua posição começam a serem ajustadas; então a Cultura Morro da Formiga assentada em TQR-61: Morro da Formiga, assume o nome de RS-S-61: Morro da Formiga, Fase Formiga e por último RS-S-61: Morro da Formiga da Fase Taquara (Miller 1966), em consideração à Fase Formiga na Ilha de Marajó). Bem, nem tudo tipológica, qualitativa e quantitativamente acerca dos atributos passou desapercebidamente ao longo dessa jornada. Algumas reconsiderações foram surgindo através de análises globalizantes: a reavaliação percentual e tipológica das cerâmicas das fases das tradições Taquara e Itararé, em 1968-69, revelou um panorama com o máximo de decoração para os sítios de várzea, ao sul, da Tradição Taquara: Fase Taquara ca. 85\% decorada, 15\% simples e Fase Guatambu ca. 70\% decorada, 15\% simples (Miller 1968, 1971) e ao longo de uma transição gradativa, mais do Sul para o Norte do que de Leste para Oeste, foi atingido um mínimo de decoração mas com formas gradativamente mais elaboradas, para o norte, para a Tradição Itararé. Esse resultado dinâmico nos levou a propor a união de "As Tradições Taquara e Itararé como uma só tradição. No XXXIX Congresso Internacional de Americanistas. Lima, Peru, 1970. 12 p., il. (inédito) (Miller 1970), inédito. Propõe-se agora que cada uma passe a representar uma Subtradição Regional, ou seja: Subtradição Taquara com suas fases, e Sutradição Itararé com suas fases.

Mas, quanto às etapas dos respectivos Formativos (Lumbreras 1974; Meggers 1999) desde as origens às difusões, houve avanço? No tocante a Fase Guatambu, foi possível reconhecer traços decorativos com técnicas e motivo 
assemelhados com os correspondentes da cerâmica Valdívia e fomon Médio (Figs, 15 e 16).

O que mais nos ocupou, foi a cultura Bacabal pré-histórica que tomou posse do Pantanal do Guaporé originou assentamentos sambaqui, agricultura incipiente da mandioca e aldeias em campo aberto nas "ilhas" florestadas, e acampamentos de estiagem na planície de inundação. O rastreamento de similaridades à cultura Bacabal, nos conduziu ao Formativo Valdívia situado no litoral equatoriano (Miller 1978a-c, 1979, 1980a-b, 1983a-b, 1985a-b, 1986a-b, 2009a), com base na excelente publicação "Early Formative Period of Coastal Ecuador: the Valdivia and Machalilla Phases" de Meggers, Betty J Meggers, Clifford Evans e Emílio Estrada (1965). A quantidade de analogias é tal que este encontro passa a ser um dos exemplos-tipo de difusão cultural material de longo alcance temporal e espacial, hoje com pelo menos uma dezena de culturas ceramistas nas duas regiões, respectivamente no litoral do Equador como doador de origem e o Pantanal do Guaporé com a Chapada dos Parecis, como receptor. Estes dois complexos cerâmicos - são portadores de exemplares com tipos facilmente confundíveis tal a semelhança entre ambas como constatei em Guayaquil, por ocasião do Simpósio Internacional de Arqueologia Sulamericana, Cuenca - Equador. 1992. (Miller 1986a-b, 1999, 2009a) (Figs. 1-5). Esse fato com início desde 1978, desviou parte de minha dedicação integral ao Brasil, para os demais países da América do Sul, a procura de analogias cerâmicas. Foi assim que dentre alguns artigos sobre o Formativo Antigo da costa Colombiana, um portador de uma imagem me chamou a atenção por apresentar um vaso em forma de "bote" no sítio Puerto Chacho (uma Fase, da Tradição ou Complexo San facinto?), "forma" que na cerâmica Bacabal vai aumentando de popularidade através do tempo. Se bem que a decoração não seja a mesma, ela é aparentemente mais Valdívia, a forma do recipiente é a de Puerto Chacho, e Bacabal propriamente. Então, estamos frente a um segundo Formativo Antigo, doador para a mesma fase cerâmica que tem aparentemente maior doação de Valdívia. Haverá um terceiro doador? Como dito páginas atrás, nos faltam artigos com abundância de boas imagens (fotográficas ou digitais, antes de desenhos), e correspondência com arqueólogos desses países, para reconhecermos quem é quem o doador e o recebedor e o quanto e quando, porque, etc.. Apesar da forma em bote não ser relatada para Valdívia, quando examinei as coleções em Guayaquil me pareceu existir fragmentos como em Bacabal que sugerem vasilhame em forma de bote, em freqüência muito baixa o que dificulta seu reconhecimento. Bacabal conta com 4.055 [3945 \pm 110 (SI-6845)] em RO-PN-8, corte 4, prof. $160-170 \mathrm{~cm}$, sem data em $190-200 \mathrm{~cm}$ que deve levar no máximo à 4.450 a.P. Puerto Chacho conta com 5.220 \pm 90 a.P (Beta-26200) em "The Earliest Ceramic technologies of the Northern Andes: a Comparative Analysis". (Raymond, Oyuela-Caycedo and Carmichael 1998). 


\section{Antecedentes}

Passados 250 anos de semi-aridez severa, entre ca. 4.350 e 4.100 a.P. ressurge o Pantanal do Guaporé com a Fase Bacabal ceramista entre 4.050700 a.P, com transição de pré-agrícola para agrícola de ca. 2.500 a 700 a.P. Assentou-se no mesmo ecossistema da Fase Guatambu pré-ceramista: nos sambaquis, sítios abertos nas "ilhas" florestadas, e na planície de inundação fluviolacustre com acampamentos de estiagem. Nossa busca, em espiral centrífuga, por semelhanças e diferenças culturais materiais à Fase Bacabal, sua origem, difusão e causas, conduziu-nos até o Formativo Antigo da Costa do Equador. Fases Valdívia e Machalilla, com ca. 5.870 a.P. (Marcos, 1988), com motivos e técnicas tanto comuns como particulares entre si, o suficiente para considerá-las como, derivadas de um Centro Formativo comum mais antigo originário do Japão (Estrada \& Meggers 1962, 1966; Estrada \& Meggers and Evans 1964; Meggers and Evans and Estrada 1965; Meggers and Evans 1957, 1965, 1966; Meggers, 1962, 1964, 1970, 1971, 1979, 1980, 1985, 1987, 1992, 1995 - 1997, 2005, 2008, 2010). O impacto climático com hiato cultural de ca. 250 anos, produziu um estrato cunhado como Estrato tipo Sinimbu-Bacabal. A Fase Valdívia que evoluiu no Óptimum Climáticum como resultado de transgressão marinha, findou com ele devido a recessão marinha, que reduziu em muito o alimento dos brejos e mangues com início ca. 4500 a.P. e colapso entre ca.4.300 e 4.000 a.P. mas, não antes da Fase Machalilla, oriunda da Guatemala (Coe 1960), se infiltrar e ficar até ca. 3.000 a. P. (Meggers \& Evans 1962; info. pes. Meggers, 2011). A difusão Valdívia se espande primeiramente pelo litoral do Pacífico para o norte da America do Sul e pela costa do Caribe até a Fase Mina; depois segue pela costa do Pacífico sul e norte; pelo golfo do México chega a Stallings-Flórida; para o leste na Amazônia pelo Ucayalli chega no Pantanal do Guaporé com a Bacabal (Miller 2009a) pelo Amazonas abaixo origina a Ananatuba. Com datas mais recentes proliferam fases em todas as direções: Baixo Xingu, a Fase Guará (Perota e Botelho 1986, 1992); seguindo até a Ponta do Jauarí com a Fase Castália e Fase fauari (Hilbert, 1959, 1968); concluindo na Ilha do Marajó, com as Fases Ananatuba, ca. 3400 a.P. e Mangueiras, ca. 3.100 a.P. da Tradição Borda Incisa (Meggers and Evans 1957, Meggers 1997) (Fig. 18).

A datação Bacabal com 4.055 a.P. apóia o início da falência e confirma a difusão/migração de Valdívia desde o litoral do Equador, se expande pelo litoral da Colômbia, da Venezuela para sudeste, pelos Llanos de Bolívia até o Pantanal do Guaporé, com as Fases Pirizal, Tradição Borda Incisa, Fase Tarioba e Fase Muiratinga no entorno noroeste do Pantanal do Guaporé (Miller 1987a), daí para o sudeste [a leste estão os Tupí dominando toda a "terra natal" (Miller 2009b)] e prossegue pela mata da encosta e pelo cerrado da borda e altiplano do Chapadão dos Parecis com as Fases Aguapé, Galera, Cajú (Miller 1974b, 1975, 1977, 1987c; Puttkamer 1979) e outras (Lima 2010); reaparecendo no 
planalto gaúcho e catarinense em meio aos falantes Xocleng, espaço físico da Fase Guatambu ca. 2.000 a.P. [1810 185 (SI-813) Subtradição Taquara, Tradição Taquara-Itararé, avançando e desdobrando adiante de minha proposição, no XXXIX Congresso Internacional de Americanistas, em Lima, Peru, 1970: "As Tradições Taquara e Itararé como uma só tradição (Taquara-Itararê)” (Miller 1970a).

Alguns paralelos cerâmicos entre Valdívia e Bacabal (Miller 2009a), são reapresentados nas Figs. 3 a 5 neste artigo. As Zonas Excisas Amplas são a diferença entre a Bacabal (Zonas Excisas Amplas) e Valdívia (Zonas Excisas Diminutas). Nas Fases inéditas: Aguapé e Galera (Simões \& Araújo-Costa 1978), esta é uma das semelhanças entre Bacabal (Zonas Excisas Amplas) e Aguapé (Zonas Excisas Amplas), e entre Valdívia, Machalilla, (Meggers, Evans and Estrada 1965), Jambeli, (Estrada, Meggers and Evans, 1964), entre FambelíEquador e Galera-Brasil (Zonas Excisas Diminutas) (Estrada, Meggers and Evans 1964). O Inciso em Linha Escalonada ocorre na Valdívia, Jambelí(raras) e na Galera (abundante); Inciso em Arco Raiado ocorre na Machalilla e na Galera. (Figs. 9, 10, 14, 15, 16). Com origens nas difusões de Machalilla, outras fases além da Bacabal, surgiram adaptadas ao entorno e "ilhas" do Pantanal do Guaporé e ao longo da encosta e borda do Chapadão dos Parecis (não inclusas nesta comunicação). As causas das difusões foram o Optimum Climáticum, que avolumou a cadeia alimentar com conseqüente pressão populacional, seguida pela regressão marinha, que reduziu a alimentação e a população, provocando, entre os sobreviventes, as dispersões/migrações por espaços com alimentos, que levaram às difusões e adaptações.

\section{Do Objetivo a ser alcançado}

Em primeiro: dar a conhecer (a quem interessar possa), um pouco de história do que movia a nossa pesquisa arqueológica nos idos de 1945 até 1980 no Rio Grande do Sul; no Sudoeste da Amazônia de 1974 ao Presente.

Em segundo: representando quase todas as culturas que descobri e conheci - menos duas que - a nível de Nota Prévia - darão a conhecer a CAUSA que moveu e move a minha arqueologia, e será melhor entendida (se houver interesse) e sem que eu o declare, através de dois trabalhos (a nível de nota prévia), porque sempre retornamos à eles; pela experiência que sempre resulta em algo mais a agregar). Um dos trabalhos versa sobre a cultura Bacabal (Miller, 2009a), um povo ceramista, pré-colonização européia, com subsistência principalmente nos gastrópodes fluviolacustres, que à meio caminho incluiu uma agricultura incipiente de Mandioca, ocupando e concluindo os sambaquis do Pantanal do Guaporé (retornaremos para apresentá-lo mais a fundo, juntamente com outros dois povos pré-ceramistas, no mesmo biótopo, apesar das mudanças climáticas, outra que viu o Pantanal surgir e iniciou os 
sambaquis, pela subsistência principalmente nos gastrópodes fluviolacustres; e uma cultura pioneira (Fase Cupim), pré-colonização européia, que nesse local acampava quando no lugar do Pantanal havia só a Depressão do Guaporé com uma savana inóspita, nem sempre seca, pelos restos de alimentação, uma vez o outra uma chuva inesperada enchia a depressão de lagunas e peixes). Esse trabalho brindou-me com as duas respostas às duas perguntas, sem as quais penso que pouco teria esclarecido em termos de arqueologia. Mas são duas respostas que geram muitas outras perguntas a espera de respostas, longe estando o trabalho conclusivo.

O segundo trabalho, quase uma odisséia amazônica (Miller 2009b), com o qual todo arqueólogo não só Sul-americano se sentiria realizado: também o é a nível de nota prévia; também brindou-me com perguntas, e respostas tidas como impossíveis, não por este aprendiz, mas por arqueólogos de renome planetário (Meggers, 1979: 57). Desde Humbold, houve muitas tentativas, sem sucesso; meus princípios e metodologia, ora centrípeta, ora centrífuga deram resultado positivo, mas para aceitá-los, os questionei por dezenas de anos até que as dúvidas se dissiparam com a ajuda de um punhado de datações C-14 dando-me a certeza suficiente para creditá-las e não refutá-las, e levá-las adiante até divulgá-las em simpósio sobre a cultura Tupi na UNB em 2007. O então trilema, hoje está voltado para a Subtradição fatuarana da Tradição Policroma.

\section{Das Fontes Arqueológicas}

A Etapa PROPPA/SI foi efetuada no Rio Grande do Sul de 1972 a 1977, e no Mato Grosso e Rondônia de 1974-75 e 1977. A título de nota prévia, os resultados que seguem foram obtidos de partes das pesquisas de campo sobre 23 sítios (p. 353, desta), efetuadas no Sudoeste Amazônico, ao longo de 197475 e 77, e mais 3 sítios em 1994 na área da então futura PCH Guaporé (Miller 1974b, 1974c, 1975, 1977).

Etapa PRONAPABA/SI (1978-80 e 1983-1986). Os cinco anos de pesquisas de campo foram cumpridos em duas etapas, intermediadas pelo mestrado. Na primeira etapa nos desdobramos com o Paleoíndio do Rio Grande do Sul e os sambaquis do Pantanal do Guaporé-Rondônia com o reconhecimento arqueológico dos rios Mamoré e Guaporé-Rondônia (Miller 1978a, 1978b, 1978c, 1979, 1980a, 1980b, 1983a). Na segunda parte, além dos sambaquis, nos ocupamos com o rio Madeira, o rio Ji-Paraná e a Br-429 a noroeste e lindante ao Pantanal do Guaporé (1985a, 1985b, 1986a, 1986b, 1986c, 1987a, 1987b).

Na época (1977) o propósito primeiro foi dar ciência ao menos das Fases Aguapé e Galera ceramistas descobertas (1974) no PROPPA, pelo seu ineditismo quanto à decoração cerâmica. Mas, com a descoberta no PRONAPABA da Fase Bacabal (1978), com uma seqüência cerâmica de 0-200 cm no sambaqui 
RO-PN-8: Monte Castelo e o elevado percentual de analogias com a cerâmica decorada da Tradição Valdívia, da qual em menor percentual a Fase Aguapé compartilha, priorizou o estudo da Fase Bacabal.

A Fase Bacabal - ceramista. Ecossistema, Pantanal do Guaporé (Fig 1 e 18) seus resíduos culturais estão assentados sobre os da Fase Sinimbu, préceramista e pré-agrícola, bem mais coletora de gastrópodes aquáticos $(96 \%)$ do que caçadora, entre 7.100 e 4.300 a.P. A segunda etapa dos resíduos dos sambaquis, foi assentada pela Fase Bacabal ceramista e pré-agrícola, com a mesma subsistência da Fase Sinimbu, entre 4.055 e 2.500 a.P., e de 2.500 à 700 a.P. também em sítios com terra preta em "ilhas" com fragmentos de alguns assadores de beijú pequenos, que sugerem uma agricultura insipiente de mandioca anexa à subsistência tradicional, como uma evolução da difusão desde a Fase Pirizal (Miller 2009a), ocorrente na periferia e "ilhas" do Pantanal do Guaporé, com traços nos atributos que também sugerem difusões ainda não identificadas. A Fase Bacabal nos pôs em contato com nosso primeiro caso marcante pela difusão da Tradição Valdívia do litoral do Equador dando origem à cultura Bacabal ceramista no Pantanal do Guaporé. Em Miller (2009a) o resumo do resultado geral, e os atributos cerâmicos (tipos, formas) a nível de seriação quantitativa, por ora, que serve de guia para as avaliações de outras fases ceramistas com paralelismos cerâmicos à Tradição Valdívia, e à Fase Bacabal. Alguns paralelos cerâmicos entre Valdívia e Bacabal (Miller 2009a), são revistos nas Figuras 2-5. Se real como parece comprovado, com base nos pró e contra atuais, fomon teria percorrido uma rota assemelhada à da Fig. 17. A rota da difusão da cerâmica que originou a cultura Bacabal partindo de Valdívia A-B é sugerida entre Guayas e Pantanal do Guaporé, com base no tipo de subsistência, acompanhando o sistema fluviolacustre até o assentamento do Pantanal do Guaporé (Fig. 1 e 18).

Enquanto entre a Bacabal (amplas) e Valdívia (diminutas), as zonas excisas amplas são uma das diferença, entre Bacabal (ampla) e Aguapé (ampla), as zonas excisas amplas são uma das semelhanças.

Entre Valdívia (diminutas), Machalilla (diminuta) e Galera (diminuta), as zonas excisas diminutas são a semelhança. Com origens nas difusões de Valdívia e Machalilla e Chorrera, outras fases além da Bacabal, surgiram no entorno do Pantanal do Guaporé RO e ao longo da encosta e borda do Chapadão dos Parecis, MT (não inclusas nesta comunicação). As causas das difusões foram o Óptimum Climáticum, que avolumou a cadeia alimentar com conseqüente pressão populacional. A regressão marinha, que seguiu, reduziu a alimentação e a população, provocou as dispersões por espaços com alimentos, que levou às adaptações e difusões.

A Fase Aguapé: $14 \mathrm{C}$ ca. 2000 a.P. [1945£55 (SI-3744) 20-30 cm em MTGU-8: Waioco] Ocupou o ecossistema florestal entre o patamar superior do Chapadão dos Parecis desde o Rio Guaritire (ou Piolho) m.d. do Rio Guaporé 
e o sistema de cerrado/mata de galeria das nascentes do Rio Camamarezinho m.e. do Rio Juruena no altiplano até o alto rio Jaurú do Paraguai, e as nascentes do Rio Buriti do Rio Juruena no altiplano (Fig. 1). Foi descoberta e registrada pelos integrantes (Simões e Araujo-Costa, 1978). A ocorrência de cerâmica no sítio MT-GU-1: Abrigo do Sol em 1974, foi a primeira da Fase Aguapé; em 1977 eram 36 em 1993 (Figs. 7 a 11 e 14). Os sítios ocorrem em campo aberto e abrigo-sob-rocha, mas só na condição primeira são sítios-habitação com terra preta, evidência de agricultura engloba a mandioca, beijuzeiros ou assadores e semissedentarismo em aldeamentos. Nesta apresentação, nos dedicamos ao tratamento de superfície, da decoração - tipos e motivos - da cerâmica Aguapé, por serem estas variáveis as mais diagnósticas para a avaliação de traços culturais entre culturas doadoras e receptoras, como já ocorreu entre Bacabal e Valdívia (Miller 2009a). Agora, o resultado das análises circularão entre Valdivia, Machalilla, Chorrera e Jambeli, e Bacabal versus Aguapé (Figs. 1 a 18). A decoração emprega a técnica do Inciso Lavrado ou Raspado e do Raspado em Baixo Relevo executado entre pós-perda da plasticidade ou desidratado e pré-queima; e a grande variedade de setores combinando motivos em losangos, triângulos e retângulos, simples, ponteados, excisos, quadriculados; dos mais simples em Triângulos Ladeados por Linhas Duplas, aos mais complexos. Um Ponto Exciso a Uma Crista Excisa é acrescido no Interior do Losango Central. (Fig. 7). Com as mesmas técnicas e processos de feitura: Decoração Reticulada; Antropomórfica Esquemática e Naturalista, com Apliques, pernas e braços; com o Hachurado representando o perfil do corpo de rã encrustado num Campo Reticulado, parte em Tabuleiro de Dama (Fig. 8). Os dois principais tipos decorados da Fase Aguapé, apresentados graficamente: (1) faixa composta pela variedade de geométricos losangulares e meio-losangos, desdobrados diagonal e transversalmente, em zonas triangulares hachuradas, e ou exciso-raspado. (2) faixa contendo zonas micro reticuladas onde se encaixa a imagem esquemática do corpo perfilado de uma rã (decúbito ventral), ladeada pelo reticulado em tabuleiro-de-dama (Fig. 9). Comparação da (1) decoração hachurada cruzada da Fase Valdívia (em baixo), da Fase Bacabal (ao meio) e da Fase Aguapé (em cima) bandas ou zonas triangulares hachuradas estão separadas por bandas de largura variável simples na Fase Bacabal, com uma ou mais linhas incisas incisões retas e paralelas na Fase Valdívia e na Fase Aguapé ou, o inciso hachurado estende-se sobre toda a superfície. (2) comparação da decoração em tabuleiro-de-damas da Fase Machalilla (no meio a direita) e da Fase Aguapé (em cima a direita) Fig. 10). Em MT-GU-17: Abrigo do Pajé. Grafismo escultórico da Fase Aguapé, representando um xamã, executado em baixo relevo (exciso $e$ inciso, contrastando a cor escura natural do arenito com musgo seco, com a cor clara das áreas em exciso (Fig. 10). Sobre a parede arenítica do patamar superior da encosta do chapadão. Em 1975 a porção direita do conjunto estava se desfazendo e irreconhecível em função da vertente que foi reativada por 
pressão do aqüífero, com perda da coesão arenítica. O corpo foi construído com linhas incisas paralelas verticais, retas e curvilíneas acompanhando a forma corpórea. O lado esquerdo do painel, é formado por outros menores cada qual com seus motivos e técnicas, os mesmos que decoram as cerâmicas. A forma do painel é retangular com ca. 4,5 m de extensão por 1,50-1,30 m de altura (Fig. 11). Encontramos outros dois Grafismo Escultórico na dolina do sítio MTGU-13: Abrigo da Chaminé.

A Fase Galera: $14 \mathrm{C}$ ca. 1.160 a.P. [1060 \pm 100 (SI-3748) 60-70 cm em MTGU-7: Galera 1] Ocupou o ecossistema do Rio Galera e afluentes desde o patamar superior até meia encosta do Chapadão dos Parecis (Fig. 1) ampliado até o sopé por Erig Lima (2011). Foi descoberta e registrada pelos integrantes (Simões e Araujo-Costa, 1978). No segundo mês de pesquisas descobrimos o primeiro sítio da Fase Galera registrado como MT-GU-07: Galera-1; em 1977 já eram seis (6) (Figs. 12 a 14). Das análises na Fase Galera, resultaram alguns traços culturais originários de Valdívia, Machalilla e Fambeli. Os sítios ocorrem em campo aberto com cemitérios em abrigo-sob-rocha e canais ou túneis, mas só na condição primeira são sítios-habitação com terra preta, evidência de agricultura engloba a mandioca, beijuzeiros ou assadores e semi-sedentarismo em aldeamentos. Como na Fase Aguapé nesta apresentação, nos dedicamos ao tratamento de superfície, da decoração - tipos e motivos - da cerâmica Galera, por serem estas variáveis a mais diagnósticas para a avaliação de traços culturais entre culturas doadoras e receptoras, como já ocorreu entre Bacabal e Valdívia (Miller 2009a). Agora, o resultado das análises circularão entre Valdivia, Machalilla, Chorrera e Fambeli, e Bacabal versus Galera (Figs. 12 a 14 e 18). A decoração da Fase Galera é elaborada com Linhas Incisas Finas, as horizontais e verticais são retas e as inclinadas são escalonadas. Os motivos: (1) reúnem paralelamente várias linhas retas e escalonadas em conjuntos espaçados entre si com gravados de aves, arco raiado (que na nossa cultura representa o sol nascente e/ou poente), etc.; ou (2) losangos e meio-losangos alternados e contínuos, cujos centros contém respectivamente uma pequena cruzeta puntiforme. cruzetas simples à encorpada, complexa, e "cristas três pontas" excisas nos ângulos internos identificando essa comunidade ou metade dentre outras que co-habitavam a região (Fig. 12). Em exemplares dos dois tipos mais abundantes da Fase Galera, ocorrem exemplares polidos enegrecidos destacando o retoque branco sobre o inciso e os emblemas. Estão presentes vasos antropomorfos, pesosde-fuso e pendentes (Fig. 13). Vínculo tipológico entre a Fase Machalilla e a Fase Galera: tipo linha inciso fino, motivo em arco raiado; vínculo tipológico entre a Fase Valdivia e a Fase Galera com: tipo linha inciso largo e profundo, e fino, motivo escalonado; vínculo temático entre a Fase Aguapé e a Fase Galera: zoogravuras. Ocorrem apliques antropomorfos (Fig. 14).

As Fases Taquara ${ }^{14} \mathrm{C}$ ca. 1.630 a.P. [ $1520 \pm 110$ (SI-414) $15-20 \mathrm{~cm}$ ] e Guatambu,

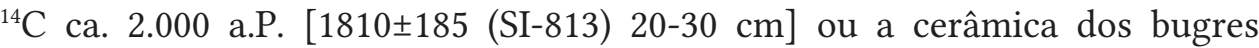


para uns, dos Kaingang/Shokleng para outros. Era conhecida desde o início da colonização européia do sudeste do Planalto Meridional, pelos colonos alemães, italianos, fazendeiros portugueses, açorianos, etc. Com as pesquisas arqueológicas do PRONAPA em 1965-66 foi cunhado o nome de Fase Taquara para essa cultura (Miller, 1967). As análises e o estudo comparativo foram revelando: dentre o tempero da argila, das formas e proporções do vasilhame, do tratamento de superfície, das técnicas e dos motivos de decoração, a semelhança de alguns desses atributos com alguns similares dentro da Tradição Valdivia, que poderiam ser conseqüências de difusões, evoluções e adaptações. Assim a Fase Taquara resistiu ao exame e passou a fazer parte da malha de culturas com origem parcial em Valdivia (Meggers, Fig. 16: 1972, 1979). Os mesmos da Fase Valdívia como vinha acontecendo entre Valdívia e muitas outras culturas envolvendo não só a cerâmica mas os artefatos líticos, ósseos, conchíferos, e suas funções. Em 1970, então com o nome abrangente de Fase Taquara, e com o mesmo propósito de revelar até onde chegaram, no espaço e no tempo, as difusões de traços culturais de Valdívia presentes na decoração da então Fase Taquara, nas formas de vaso, técnicas e motivos.

A Fase Guatambu foi descoberta e cunhada em 1968, durante o quarto ano do PRONAPA entre 1968-69 com as pesquisas arqueológicas efetuadas no Planalto Meridional (Miller, 1971). Se as análises e os estudo comparativo entre a Fase Taquara e a Tradição Valdívia revelaram algumas semelhanças quanto algumas formas entre o vasilhame de ambas, no tratamento de superfície, das técnicas e motivos de decoração, as semelhanças entre a Fase Guatambue a Fase Valdívia em alguns desses atributos não deixa dúvida alguma quanto a difusão entre vários atributos análogos dentro da cerâmica fomon, Tradição Valdívia e da Fase Guatambu (Figs. 15, 16 e 17) que possui tipológica e quantitativamente os atributos mais assemelhados e preservados em relação aos traços da Fase Taquara. Elas poderiam ser conseqüências de difusões, adaptações alteradas pela variação geomorfológica, climática e ecológica, do Pacífico com correntes marinhas frias, perpassando uma imensa continentalidade em diagonal, do noroeste para o sudeste até o Atlântico com correntes marinhas tanto quentes como frias. Assim, a Fase Guatambu com ca. 70\% decorada-15\% simples como a Fase Taquara, com ca. $85 \%$ decorada-15\% simples, passou a fazer parte da malha de culturas com origem em Valdívia (Meggers, 1970,1972, 1979; Miller 1968, 1971) (Figs. 15 e 16). As mesmas doações da Fase Valdívia como vinha ocorrendo entre Valdívia e outras culturas recebedoras envolvendo não só a cerâmica mas os artefatos líticos, concha e chifre, em coleções maiores.

\section{Discussões e Conclusões}

A minha busca pelo estágio insipiente das cerâmicas, com as quais me fui deparando, teve como primeiro resultado a cerâmica Bacabal dos sambaquis 
de água doce do Pantanal do Guaporé, RO-BR, com analogias na cerâmica da Tradição Valdívia da Costa do Equador, com baixa subsistência de molucos marinhos, não resultando em sambaquis. Aportaram com cerâmica já evoluída há ca. 5.800 anos atrás, derivada da cerâmica fomon Médio da ilha japonesa de Kiushu, cujo estágio Insipiente ocorreu ca. 13.000 a. P. Na América se difundiu amplamente por ambos os hemisférios até latitudes subtropicais.

Várias outras culturas cerâmicas originárias de sambaquis de águas marinhas, salobras e doce tem revelado uma antiguidade ao redor de 4.000 a 7.500 a.P. e teria a cerâmica Taperinha como a mais antiga, com base em datações, segundo Roosevelt, mas com tipos cerâmicos de decoração Barlovento e Manacapuru (que não atingem os 4.000 a.P. na Amazônia Central que contam com menos da meia idade da antigüidade obtida $(3500+/-100-$ 2800+/-80a.P.) na Colômbia. E temos ainda o nível das águas do Amazonas que no máximo do Óptimum Climáticum (5.500 anos a.P.), mais quente e mais chuvoso, com o nível fluvial e das marés de então, bem maiores que as atuais, que deveria chegar até quase a confluência do Amazonas com o Negro. Para Taperinha, deveria ser um problema pela posição altimétrica em que ele se encontra. E enquanto não for esclarecida essa série de obstáculos para o aceite ou não da antiguidade de Taperinha, ela permanece uma questão em aberto.

A quantidade das coleções cerâmicas antigas, afora as da Colômbia e Equador são muito pequenas; e com problemas dificilmente solucionáveis; enquanto assim for, a única candidata com possibilidades de ser a cultura formativa autóctone mais antiga é a San Jacinto 1. Contudo foi a segunda a Valdívia que claramente se dispersou, colonizou e se difundiu pelas três Américas. A antiguidade das cerâmicas em sambaquis de água doce, são abundantes mas não ultrapassam a 4.050 a.P. com referência ao sambaqui Monte Castelo da cultura Bacabal, cujo Corte-4, 2x2x2m (8m3) produziu 3.312 fragmentos de vasilhame com decorados entre 13,04 e 23,86\% (Miller 2009a), e Taperinha é problemática como visto acima. Como as regiões são muito grandes e muito pouco pesquisadas, toda a afirmação sempre se refere ao conhecimento pontual do momento.

A continuidade das pesquisas, sobre a origem das cerâmicas: da Tupiguaraní da Faixa Costeira do Brasil, resultou na descoberta da sua origem do seu estágio insipiente em desenvolvimento na região do alto Ji-Paraná, RO, Brasil; a primeira tradição com origem em território brasileiro donde se expandiu pelas terras baixas da America do Sul: o tipo Pintado para o Oriente e o tipo Corrugado Complicado para o Ocidente.

A análise do acervo arqueológico aponta para várias outras Tradições cujos princípios incipientes são desconhecidos cobrindo vastas regiões como a Tradição Policroma com várias subtradições mas que resiste em revelar 
sua origem, que para o leste não é, e com resultados como o da Subtradição fatuarana a mais antiga apontando para fora do Brasil, talvez para oeste, para o alto Beni. Entre essas tradições maiores ocorrem nos afluentes menores o que comumente se nomeia de Tradições Regionais; cuja diversidade é grande como a Amazônia; no rio Marmelo afluente do Madeira com datas até 7300 anos a.P. por serem creditadas.

\section{Parte dos Sítios e Fases Arqueológicos das Pesquisas Arqueológicas. Mato Grosso e Rondônia. PROPPA- Programa Paleoíndio e Paleoambiente. MARSUL, SI e NGS. 1974-1977}

MT-AJ-1: Camararézinho, Camararé, 150x80m, mataciliar-Ig. Camararézinho-197720 km BR-364,1974; S/A-C 1978.

MT-AJ-2: Posto Fritz, Aguapé, 300x190m, mata ciliar-Ig. Juina-Posto da FUNAI,20 km BR-364,1975; S/A-C 1978.

MT-AJ-3: Cerro Azul, Aguapé, 180x110m, mata ciliar-Ig. Juina-Posto da FUNAI Cerro Azul-1974- 20 km BR-364,1974; S/A-C 1978.

MT-AJ-4: Formiga-1, pré-cerâmico, Jatobá, 1977; S/A-C 1978.

MT-AJ-5: Formiga-2, Aguapé, 100x60m,cerrado-rio formiga afl. juruena-5km da faz. Formiga/montedam-1977;S/A-C 1978.

MT-GU-1: Abrigo do Sol, Aguapé (2.500 a.P.), Poaia, Dourado,180x110m,Rio Gal.Faz.Aguapé-mata-Ig. Dourado-20km BR-364-1974; S/A-C 1978.

MT-GU-2: Aldeia Velha-1, Aguapé, 130x70m,cerrado,ig,4km de MT-GU-1, faz. aguapé, 1974-5; S/A-C 1978.

MT-GU-3: Montedam-1, Aguapé, 180x70m, km560BR-364, 16km da faz. Montedam, 1975; S/A-C 1978.

MT-GU-4: Montedam-2, Aguapé, 250x100m, km560BR-364, 13km da faz. Montedam, 1974-75; S/A-C 1978.

MT-GU-5: Montedam-3, Aguapé, 200x80m, km560BR-364, 10km da faz. Montedam, prox. PCA-Uirapuru,1974-75; S/A-C 1978.

MT-GU-6: Sorana, Caju, 140x90m, 40 km da faz. Montedam km560BR-364,1975; S/A-C 1978.

MT-GU-7: Galera-1, Galera, 160x80m, 25km da BR364 e da faz. Aguapé,km550,1975; S/A-C 1978.

MT-GU-8: Waioco, Aguapé, abrigo cerimonial e acampamento a $200 \mathrm{~m}$ ao sul de MT-GU-1, 20km da BR-364, da faz. aguapé,1974-75; S/A-C 978 MT-GU-9: Aldeia Velha-2, Aguapé, mata 200m de ig. Entre MT-GU-1 e MT-GU-2, faz. Aguapé, a 20 km da BR-364, 1974; S/A-C 978. 
MT-GU-10: Abrigo do Igarapé, Aguapé, cerim./acamp. 19km da BR-364, 2 abrigos geminados a 1km de MT-GU-2, faz.aguapé, 1974; S/A-C 1978.

MT-GU-11: Abrigo da Onça, Aguapé Acamp./cerim.,entre MT-GU-6 e MT-GU-8, 20km da BR-364, km620, 1974; S/A-C 1978MT-GU-12: Abrigo do Lago, Galera, Acamp./cerim.,em caverna, 15km da BR-364, km 580, faz.aguapé, 1974; S/A-C 1978.

MT-GU-13: Abrigo da chaminé, Aguapé, Acamp./cerim.,em caverna, 15km da BR364, km580, faz.aguapé, 1974; S/A-C 1978.

MT-GU-14: Aguapé-1, Aguapé 250x100m, km560BR-364, 13km da faz. Montedam, 1974-75; S/A-C 1978.

MT-GU-15: Aguapé-2, Aguapé 170x90m prox, sede faz. Aguapé, mata, 36km BR364, km 610,1974; S/A-C 1978.

MT-GU-16: Duas Moças, Aguapé, 190x100m prox, sede faz. Santa Terezinha, mata, 50km BR-364, km 690,1974-75; S/A-C 1978.

MT-GU-17: Abrigo do Pajé, Aguapé 15km BR-364, km 615,1974-75; S/A-C 1978.

MT-GU-18: Rio Novo, Aguapé, 350x300m, floresta, afl. galera m.e.1977; S/A-C 1978.

MT-GU-19: Galera-2, Aguapé, 150x80m, ca. 3km ao norte deMT-GU-7: Galera I,floresta c. roça nambiquara, 1977; S/A-C 1978.

MT-GU-20: Usina-1, Jatobá, 200x100m, sítio oficina pré-cer., na flor./cerr. Entre 2 ig. PCH da Montedam BR-364, km 690,1977; S/A-C 1978 .

MT-GU-21: Aguapé-3, Aguapé, 300x200m, mata/pasto, faz.Aguapé, 38km da BR364, km620, 1977; S/A-C 1978.

MT-GU-22: Rio Verde-1, Tracajá, 150x100m, Faz. Guaporé,1977; S/A-C 1978.

MT-GU-23: Rio Verde-2, Tracajá, 120x80m, , Faz. Guaporé,1977; S/A-C 1978.

MT-GU-24: Rio Verde-3, Neobrasileiro, 100x100m, , Faz. Guaporé,1977; S/A-C 1978.

MT-GU-25: Betânia-1, Sucurí, 300x160m, 1977; S/A-C 1978.

MT-GU-26: Betânia-2, Sucurí, 100x70m, 1977; S/A-C 1978.

MT-GU-27: Tamanduá, Proto-Tupiguaraní, 110x70, 2km NWde MT-GU-1, Faz. Aguapé- mata/cerr.Ig. Dourado-22km BR-364,1974-77;

MT-GU-28: Usina-2, Galera, 260x120m, sítio na mata/cerr., entre 2 ig. 1,5km da PCH da Montedam50km BR-364, km 688,1977;.

MT-GU-29: Usina-3, Galera, abrigo funerário na mata/cerr., entre 2 ig. 1,5km da PCH da Montedam 50km BR-364, km 688,1977;

MT-GU-30: Usina-4, Galera, canal abrigo funerário na mata/cerr., a leste da PCH 300m Montedam,1977;

MT-GU-51: Guaporé-1, Aguapé(Miller 1994); ou Guapé 1, resgate por Wüst-IGPA/ 
UCG-1999, m.e. Rio Guaporé sob eixo barragem da PCH Guaporé;.

MT-GU-52: Guaporé-2, Aguapé (Miller 1994); ainda não resgatado por por WüstIGPA/UCG. Na m.e. Rio Guaporé 4 kn acima de Guapé 2;.

MT-GU-53: Guaporé-3, Aguapé(Miller 1994); ou Guapé 2, resgate por Wüst-IGPA/ UCG-1999, m.d. Rio Guaporé, a ser inundada, lago PCH Guaporé; ).

CULTURAS: AGUAPÉ - 19 sítios (AJ-2 e 3, 5; GU-1 a 5; 8 a 10 e 11, 51 a 53); CAMARARÉ - 1 sítio (AJ-1); JATOBÁ - 1 sítio (GU-20); TRACA JÁ - 2 sítios (GU22 e 23); GALERA - 4 sítios (GU-7 e 28 a 30); CAFU - 1 sítio (GU-6); PROTOTUPIGUARANI - 1 sítio (GU-27); SUCURI - 2 sítios (GU 25 e 26); NEOBRASILEIRO - 1 sítio $G U$ 24) = 36 sítios.

BIBLIOGRAFIA: Miller 1974b, 1975, 1977, 1986a-c, 1987a-b, 1994; Simões 1972; Araujo-Costa 1978.

\section{Legendas}

Fig. 01 - Áreas mínimas de ocupação. Da Fase Bacabal no Pantanal do Guaporé, Rondônia-Brasil representada por 12 sítios, sendo 2 sambaquis, 9 acampamentos sazonais e 1 em "ilha" com terra preta. Da Fase Aguapé com 22 sítios no patamar superior do Chapadão dos Parecis desde o Rio Guaritire (ou Piolho) m.d. do Rio Guaporé e as nascentes do Rio Camamarezinho m.e. do Rio Juruena no altiplano até o alto rio Jaurú do Pantanal do Mato Grosso, e as nascentes do Rio Buriti do Rio Juruena no altiplano. Da Fase Galera, com 07 sítios-habitação com terra preta, do patamar superior à meia encosta do Chapadão dos Parecis, entre o Rio Novo e um afluente do Córrego Banhado, ambos afluentes do Rio Galera. Pesquisas de Erig Lima (2011) encontra a Fase Galera junto de outras fases no sopé do chapadão, que parecem ter ligação com cerâmicas da Costa do Equador.

Fig. 02 - Fase Bacabal: variedade dos tipos com técnicas incisas e excisas, em vasta gama de motivos, empregadas na decoração plástica, mista ou plástica com engobo ou banho, em extensa gama do vermelho (alaranjado à vinho nesta cerâmica, ao longo de 3.350 anos de 4.050 até 700 anos atrás.

Fig. 03 - Comparação da decoração incisa em zigue-zague da Fase Bacabal (em cima) com a da Fase Valdívia (em baixo). Uma banda horizontal zigue-zague define zonas triangulares com incisões paralelas (Fase Bacabal) ou cruzadas (Fase Valdivia) adjacentes à borda, ou bandas intersectadas definem zonas em forma de diamante com o mesmo tratamento.

Fig. 04 - Comparação da decoração incisa da Fase Bacabal (em cima) e da Fase Valdívia (em baixo). Zonas de incisões paralelas retas ou ligeiramente curvadas têm intersecções angulares que tendem a transpassarem-se.

Fig. 05 - Comparação da decoração Hachurada Cruzada da Fase Bacabal (em cima) e da Fase Valdívia (em baixo) Bandas ou Zonas Triangulares Hachuradas 
estão separadas por bandas de largura variável simples na Fase Bacabal e com uma ou duas incisões retas paralelas na Fase Valdívia, ou a decoração Incisa Hachurada estende-se sobre toda a superfície.

Fig. 06 - Subtradição fatuarana, Tradição Policroma com cerâmica altamente desenvolvida e elaborada já há 3.000 a.P. Desde o baixo rio Mamoré (Guajará Mirim-RO) à região de entorno à desembocadura do rio Madeira com o rio Amazonas-AM. Nessa extensão, variações e combinações inclusive com Tradições Regionais, sugerem o desdobramento das subtradições em fases, tarefa esta que demandará o domínio de conhecimentos ainda não existente. Entre os fragmentos com decoração plástica e pintada multicor com bordas trabalhadas em recortes escalonados e sinuosos, se destaca uma urna funerária antropomorfa, cuja forma é comum e predominante nesta subtradição.

Fig. 07 - Fase Aguapé - decoração com técnica do inciso lavrado ou raspado e do raspado em baixo relevo executado entre pós perda da plasticidade ou desidratado e pré-queima; e a grande variedade de setores combinando motivos em losangos, triângulos e retângulos, simples, ponteados, excisos, quadriculados; dos mais simples em triângulos ladeados por linhas duplas, aos mais complexos. Um ponto exiso a uma crista excisa é acrescido no interior do losango central.

Fig. 08 - Fase Aguapé: mesmas técnicas e processos de feitura. Decoração reticulada; antropomórfica esquemática e naturalista, com apliques, pernas e braços; com o hachurado representando o perfil do corpo de rã encrustado num campo reticulado, parte em tabuleiro de dama.

Fig. 09 - Os dois principais tipos decorados da Fase Aguapé, apresentados graficamente são: (1) faixas compostas pela variedade de geométricos losangulares e meio-losangos, desdobrados diagonal e transversalmente, em zonas triangulares hachuradas, e ou exciso-raspado. (2) faixa contendo zonas micro reticuladas onde se encaixa a imagem esquemática do corpo perfilado de uma rã (decúbito ventral), ladeada pelo reticulado em tabuleiro-de-dama.

Fig. 10 - Comparação da (1) decoração hachurada cruzada da Fase Valdívia (em baixo), da Fase Bacabal (ao meio) e da Fase Aguapé (em cima) bandas ou zonas triangulares hachuradas estão separadas por bandas de largura variável simples na Fase Bacabal, com uma ou mais linhas incisas incisões retas e paralelas na Fase Valdívia e na Fase Aguapé ou, o inciso hachurado estende-se sobre toda a superfície. (2) comparação da decoração em tabuleiro-de-damas da Fase Machalilla (no meio a direita) e da Fase Aguapé (em cima a direita).

Fig. 11 - MT-GU-17: Abrigo do Pajé. Grafismo escultórico da Fase Aguapé, representando um xamã, executado em baixo relevo (exciso e inciso, contrastando a cor escura natural do arenito, com a cor clara das áreas em exciso) sobre a parede arenítica do patamar superior da encosta do chapadão. Em 1975 a porção direita do conjunto estava se desfazendo e irreconhecível em 
função do musgo da vertente que foi reativada por pressão de aqüífero, com perda da coesão arenítica. O corpo foi construído com linhas incisas paralelas verticais, retas e curvilíneas acompanhando a forma corpórea. O lado esquerdo do painel é formado por outros menores cada qual com seus motivos e técnicas, os mesmos que decoram a cerâmica Aguapé. A forma do painel é retangular com ca. 4,5 m de extensão por 1,50-1,30 m de altura. Encontramos outros dois Grafismo Escultórico na dolina do sítio MT-GU-13: Abrigo da Chaminé; foi elaborado à luz de fogueira no fundo escuro da dolina; os grafismos a carvão estão concentrados na porção frontal e clara da abertura do abrigo.

Fig 12 - A decoração da Fase Galera é elaborada com linhas incisas finas. As horizontais e verticais são retas e as inclinadas são escalonadas. Os motivos: (1) reúnem paralelamente várias linhas retas e escalonadas em conjuntos espaçados entre si com gravados de aves, arco raiado (que na nossa cultura representa o sol nascente e/ou poente), etc.; ou (2) losangos e meio-losangos alternados e contínuos, cujos centros contém respectivamente uma pequena cruzeta puntiforme. cruzetas simples à encorpada complexa, e "cristas três pontas" excisas nos ângulos internos identificando essa comunidade ou metade dentre outras que co-habitavam a região.

Fig. 13 - Em exemplares dos dois tipos mais abundantes da Fase Galera, ocorrem exemplares polidos enegrecidos destacando o retoque branco sobre o inciso e os emblemas. Estão presentes vasos antropomorfos, pesos-de-fuso e pendentes.

ig. 14 - Vínculo tipológico entre a Fase Machalilla e a Fase Galera: tipo linha inciso fino, motivo em arco raiado; vínculo tipológico entre a Fase Valdívia (?) e a Fase Galera com: linha tipo inciso largo e profundo, e fino, motivo escalonado; vínculo temático entre a Fase Aguapé e a Fase Galera: zoo-gravuras. Ocorrem apliques antropomorfos.

Fig. 15 - Alguns traços culturais similares entre fomon, Valdívia (Estrada, Meggers and Evans 1965) e Guatambu, através de alguns tipos Cerâmicos (Miller 1971, Est. 9 e 10; esta Fig. e Fig. 16).

Fig. 16 - Vasilhame Guatambu e Valdivia; formas distintas mas tipo de decoração similar Guatambu é a difusão mais longínqua da origem Valdívia que é o doador principal dessa longa série de doações e recepções culturais cerâmicas e em alguns exemplos, também do material de expediente, cujo exemplo é o receptor Bacabal.

Fig. 17 - Acima: Sentido da corrente marinha facilitando migrações para a América por ocasião de impactos ambientais, devido a erupções vulcânicas como a ocorrida em 6300 a.P., com possíveis arrastes de barcos em eventos migratórios pós desastres ecológicos ocorridos, dificultando a sobrevivência e desencadeando por repasse a cultura fomon renomeada de Valdívia em território da Costa do Equador. Abaixo: Valdivia nos episódios A - B, do 
início a 4000 a.P. entre as ocorrências arqueológicas com traços culturais derivados da Fase Valdívia-c e outras culturas ceramistas posteriores ao longo do Caminho Andino-Amazônico Pastaza Guaporé (fontes: Athens 1984; Lathrap 1975; Meggers 1972, 1979; Meggers, Evans, Estrada 1965; Miller 1978, 1980, 1983, 2009; Porras 1975; Weber 1975). Complexos com nomes em parêntesis são mais recentes, mas, incorporam tratamentos de decoração mais remanescentes. Na planície do Rio Guaporé médio, entre a m. d. do Rio e Pantanal do Guaporé, ocorrem fases mais recentes ocorrendo nesse trabalho as primeiras investigações sobre vínculos com as Fase Valdívia e Bacabal, como: Limeira, Mateguá; Corumbiara e Pimenteira (Miller 1980, 1983). já as Fases recentes: Pirizal, Tarioba e Muiratinga (entorno do Pantanal do Guaporé), Aguapé, Galera e Caju, nos patamares do Chapadão dos Parecis, apresentam traços que sugerem relações remanescentes com as fases Valdivia, Machalilla, Pastaza,Chorrera e Bacabal (Miller 1974-1980, 1994, 2009a). As fases próximas ao Rio Guaporé ocorrem em ambas às margens.

Fig. 18 - Alguns acréscimos no mapa da difusão de manufatura cerâmica no Novo Mundo, de Meggers (1979), com novas descobertas de fases portadoras de difusão de traços de tipos cerâmicos de Valdívia, Machalilla, Correra e Fambeli, distribuídas no centro da América do Sul, junto ao Pantanal do Guaporé e Chapadão dos Parecis.

\section{Figuras}

\section{FIGURA 1}

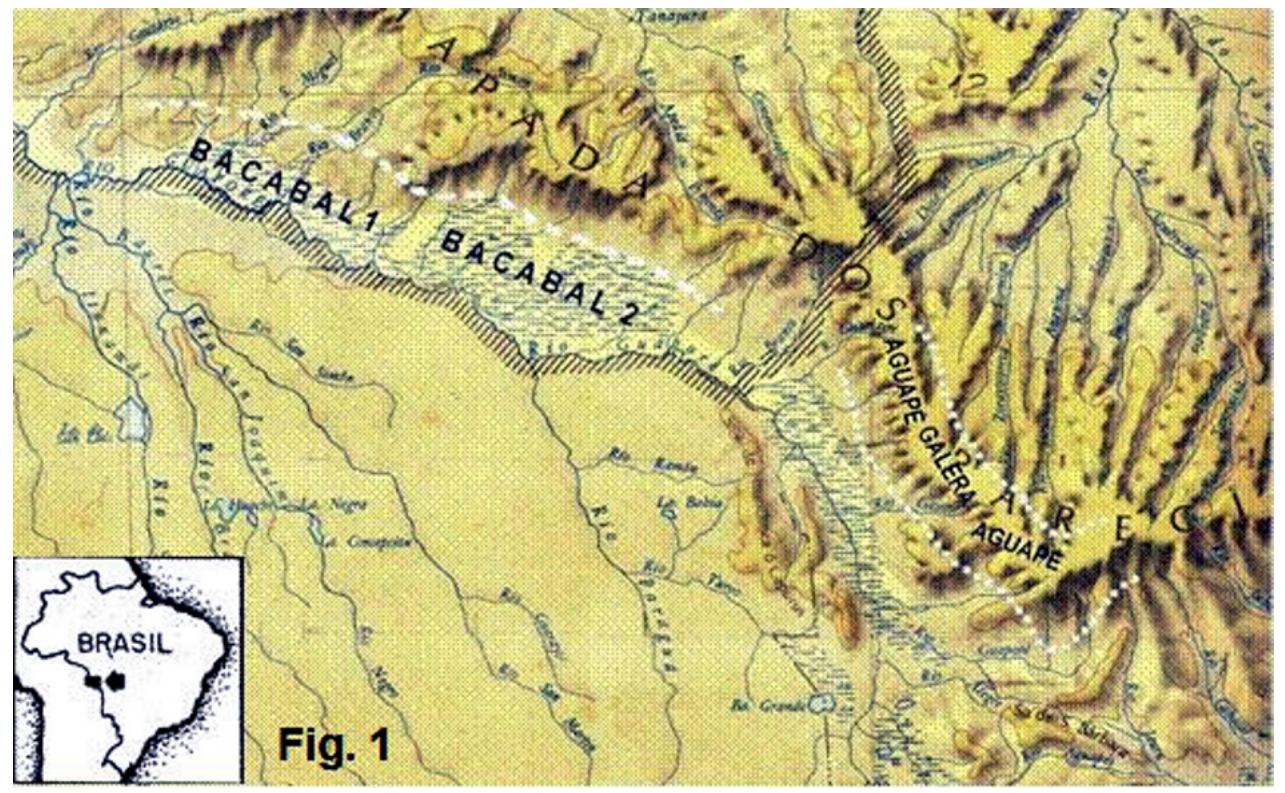


FIGURA 2

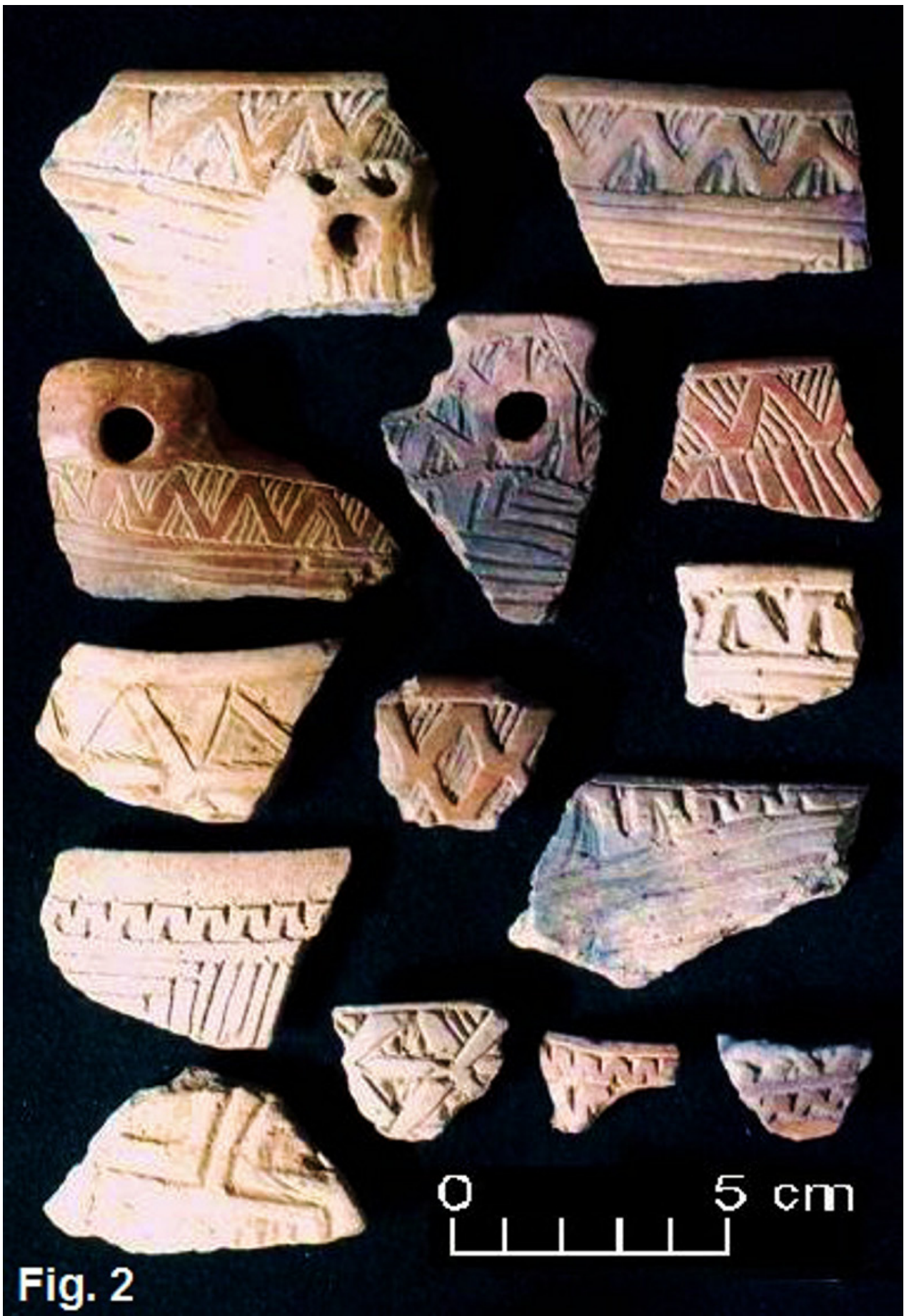

Volume 5, Número 2, Dezembro de 2013363 
FIGURA 3
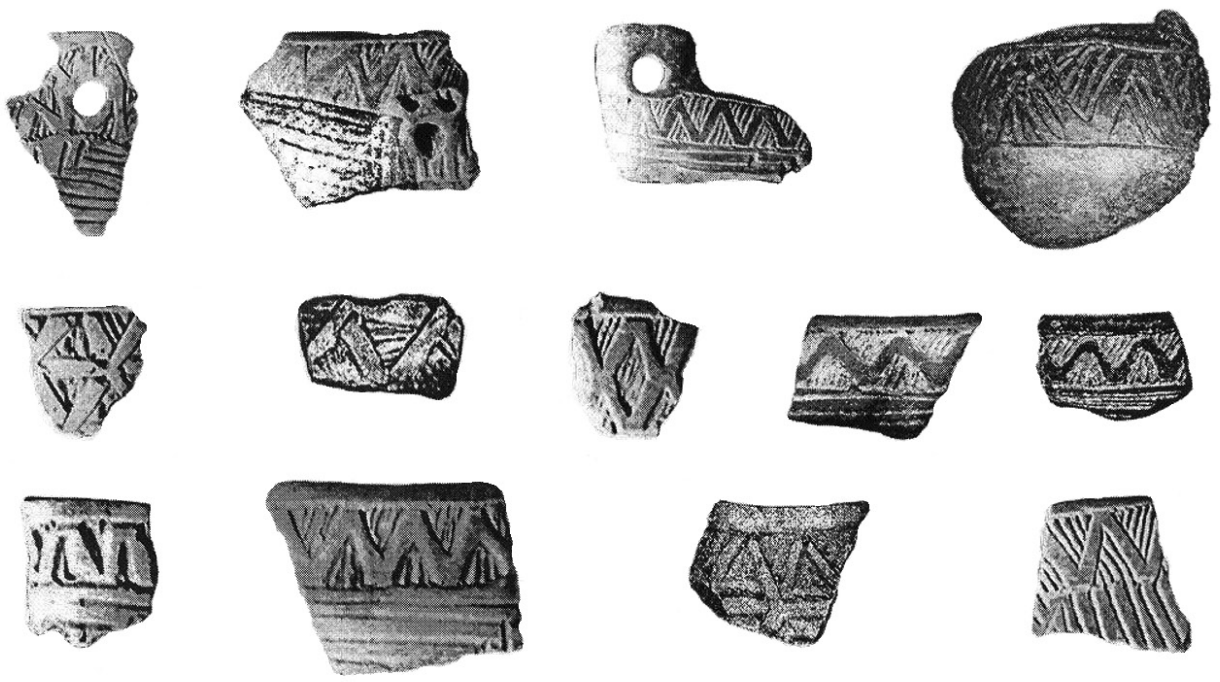

\section{BACABAL}
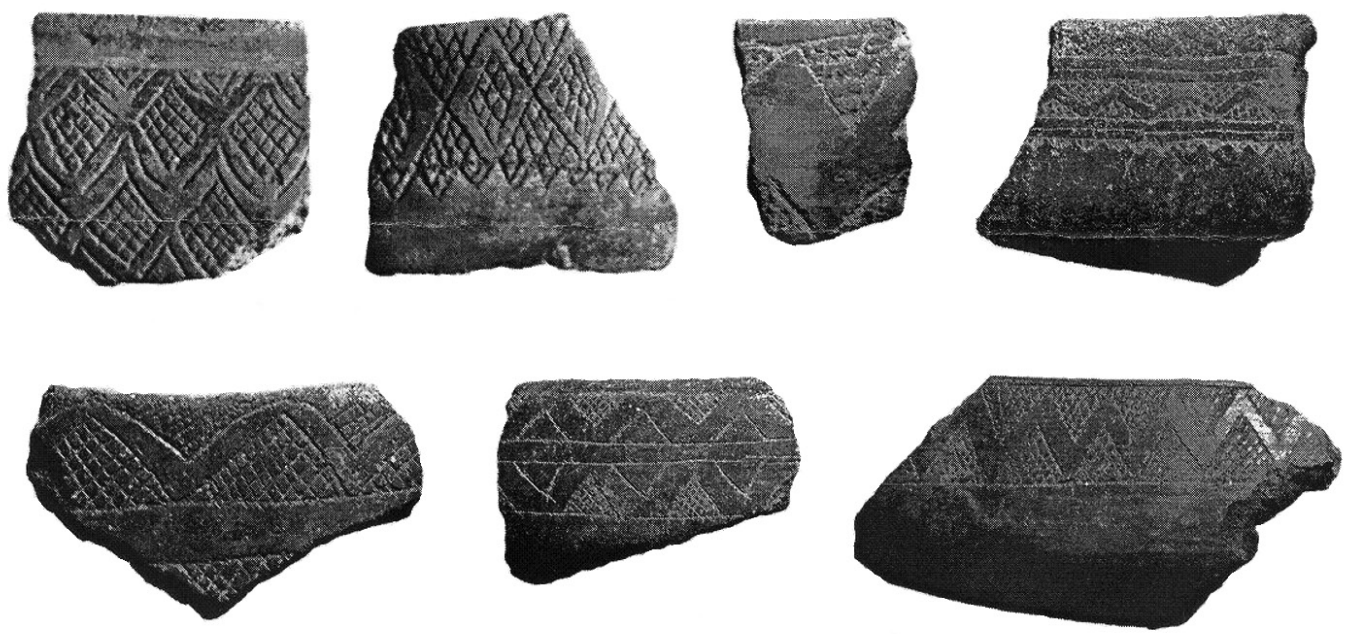

VALDÍVIA 
FIGURA 4
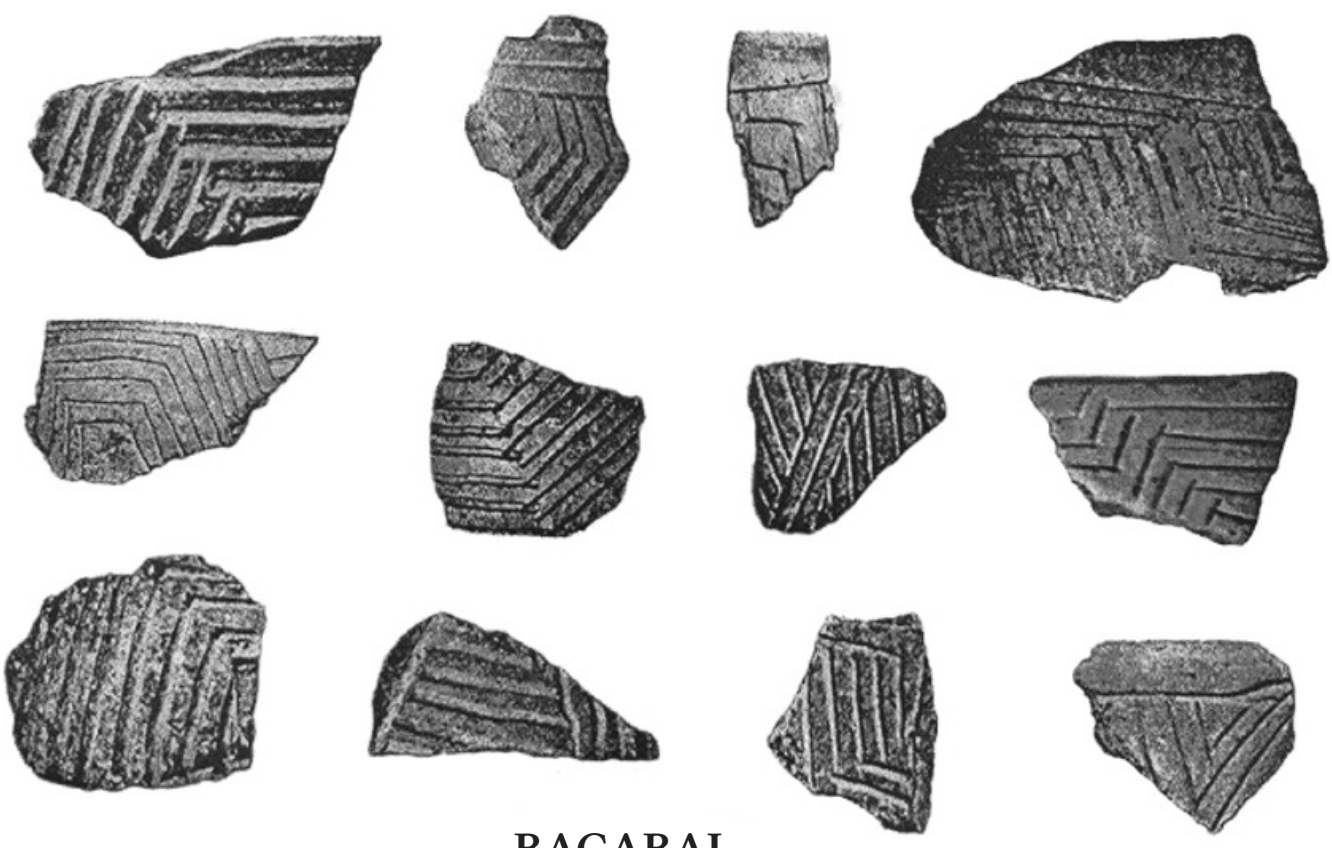

\section{BACABAL}
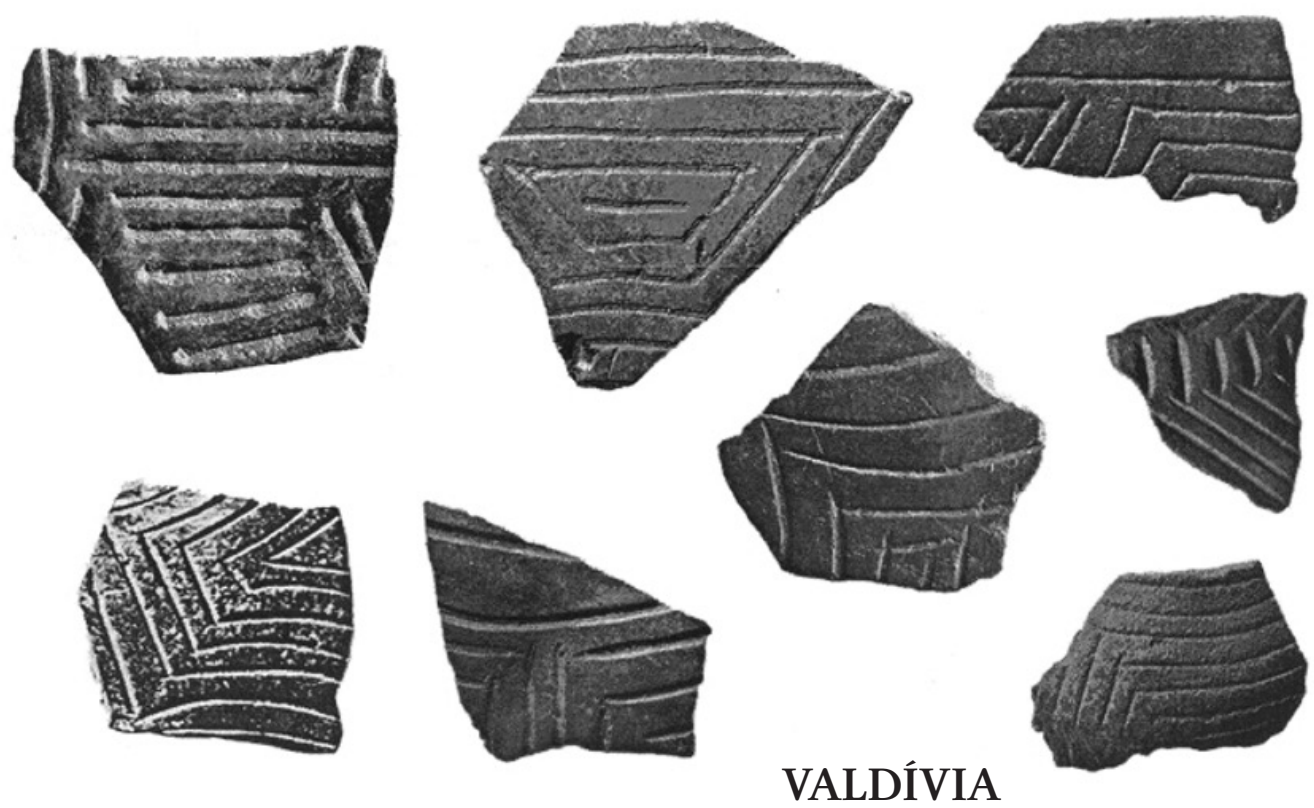

VALDÍVIA

Volume 5, Número 2, Dezembro de 2013365 
FIGURA 5
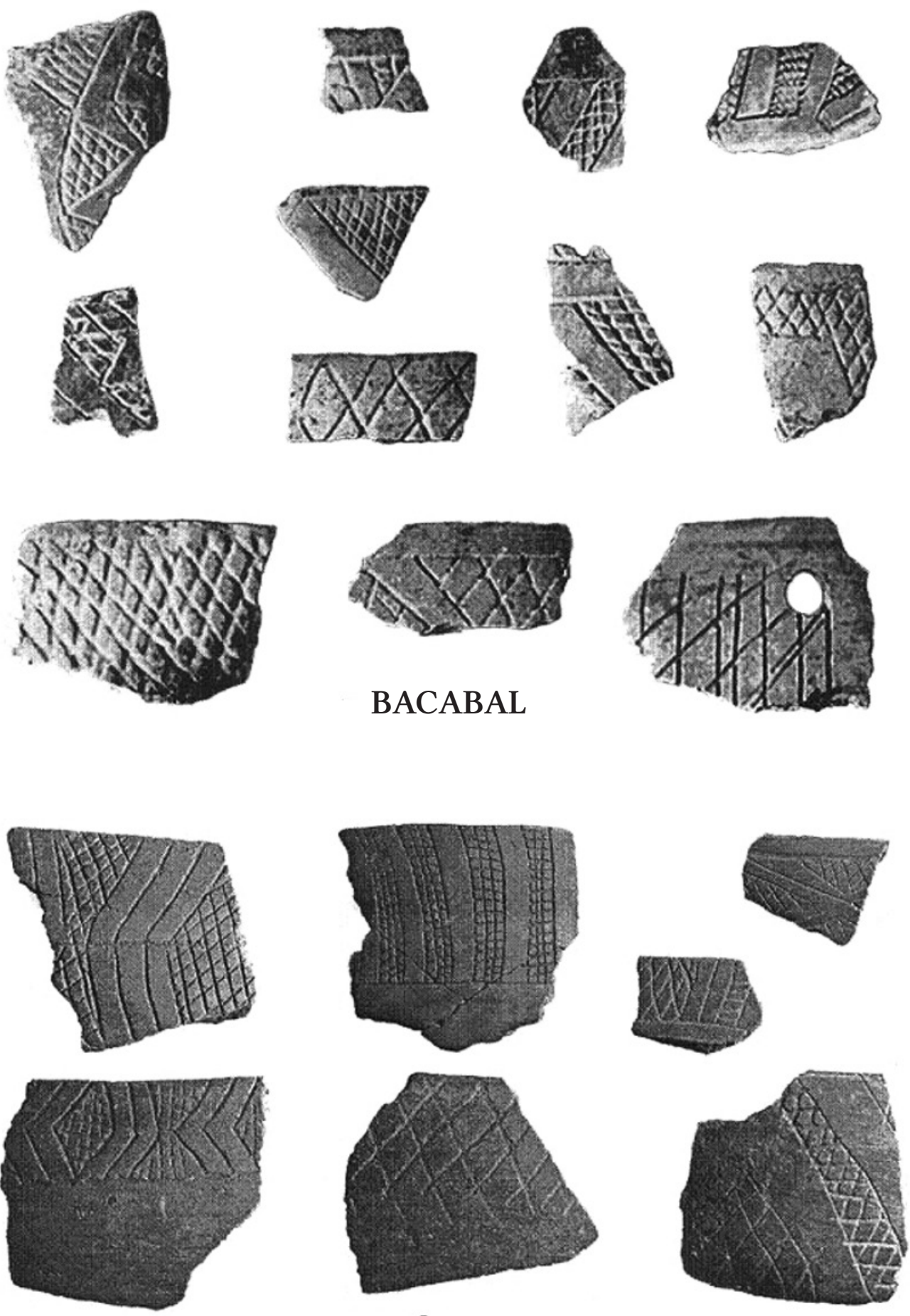

VALDÍVIA

366 Revista Brasileira de Linguística Antropológica 
FIGURA 6

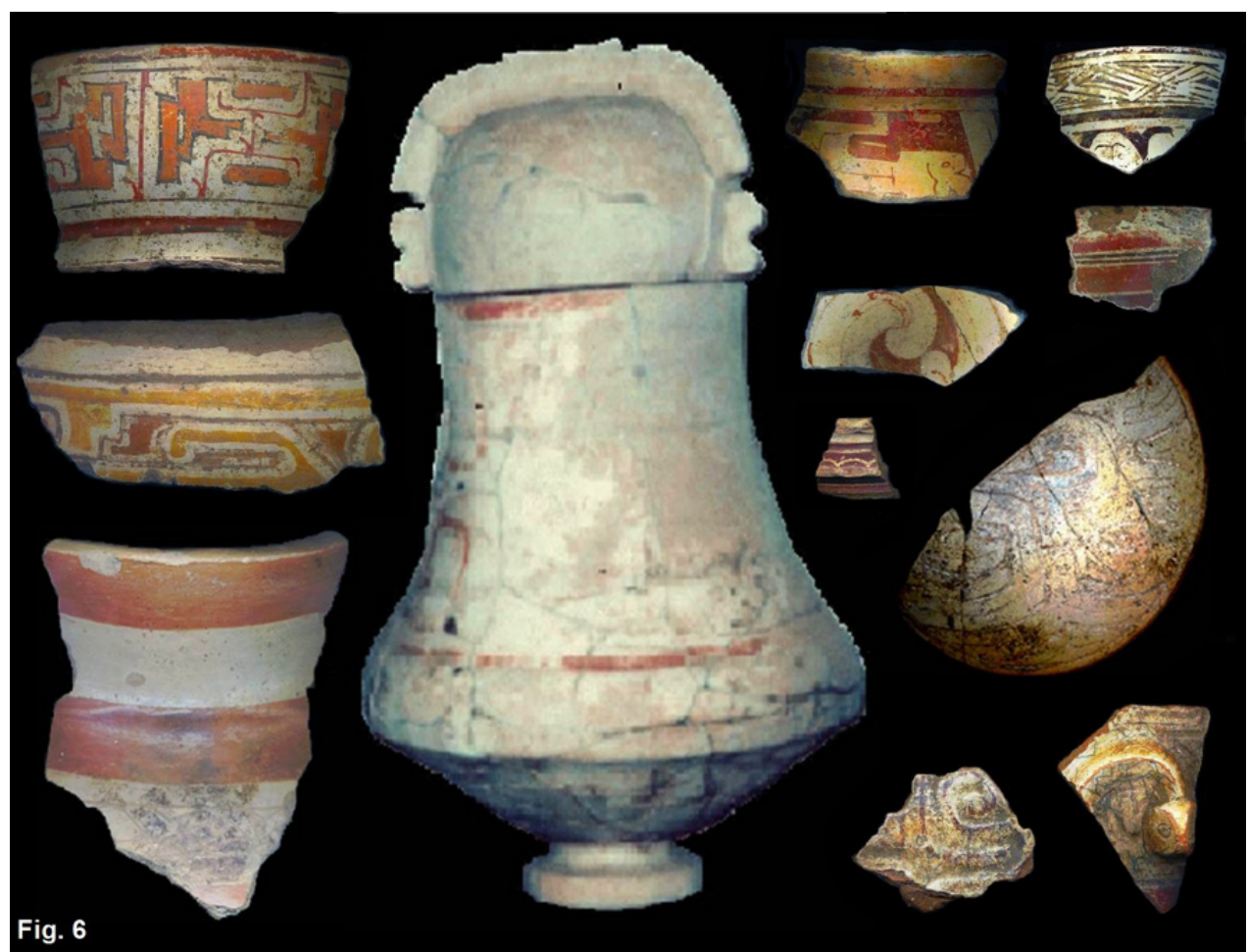

FIGURA 7

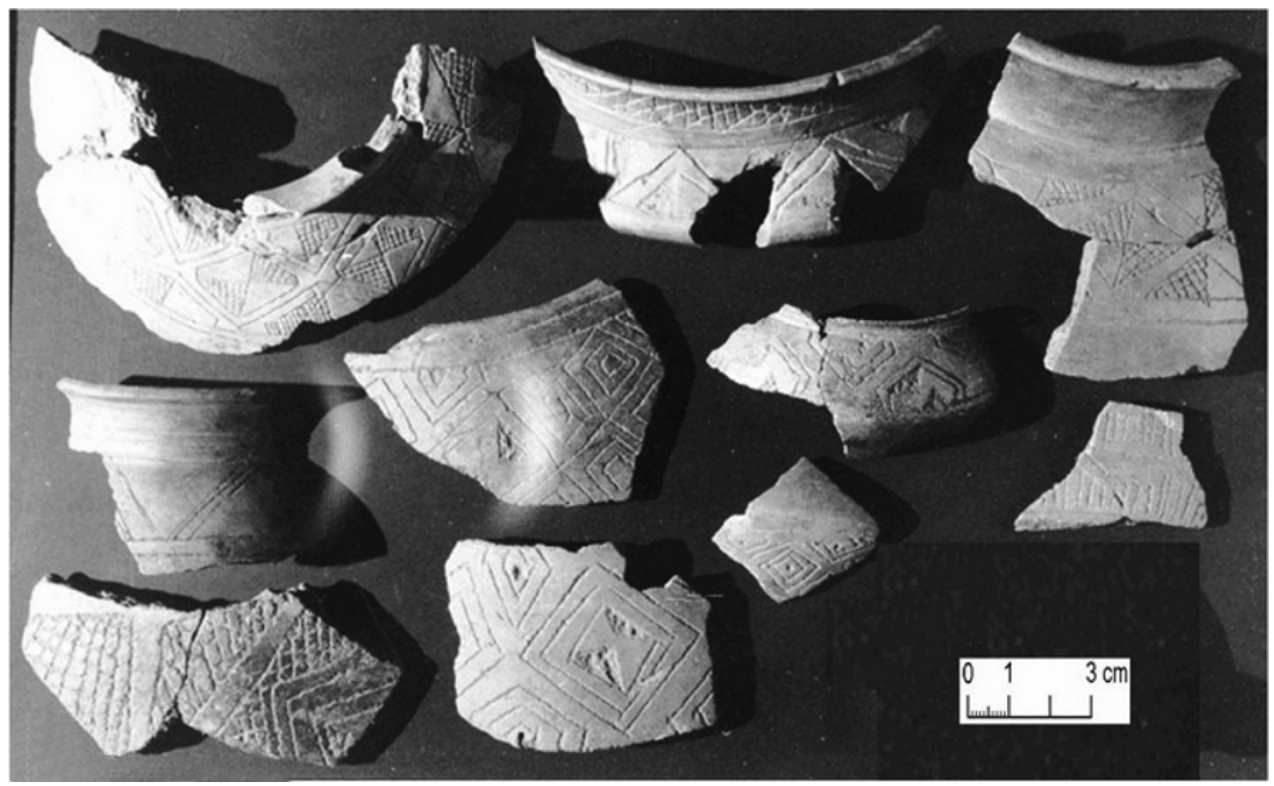

Volume 5, Número 2, Dezembro de 2013367 
FIGURA 8

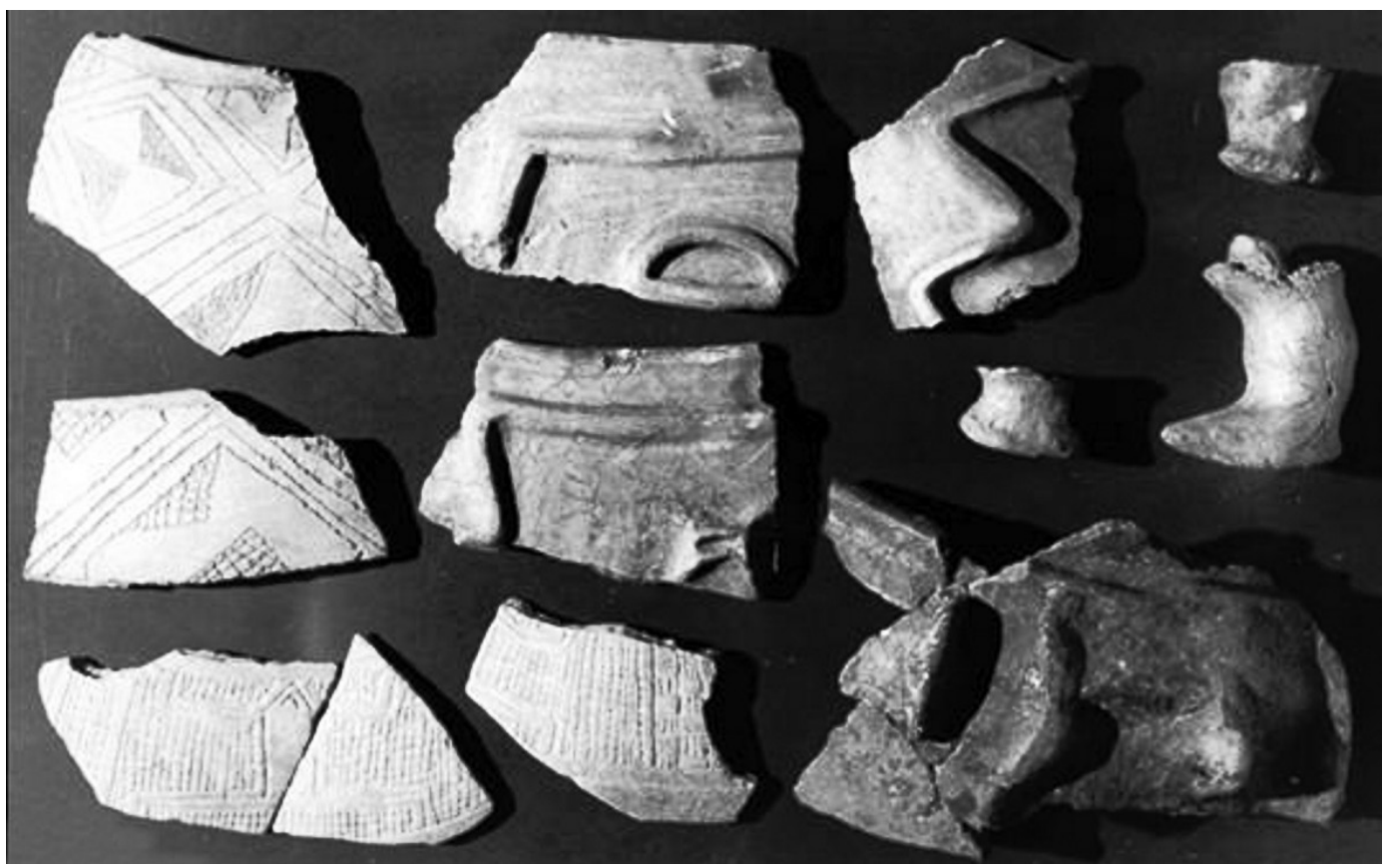

FIGURA 9

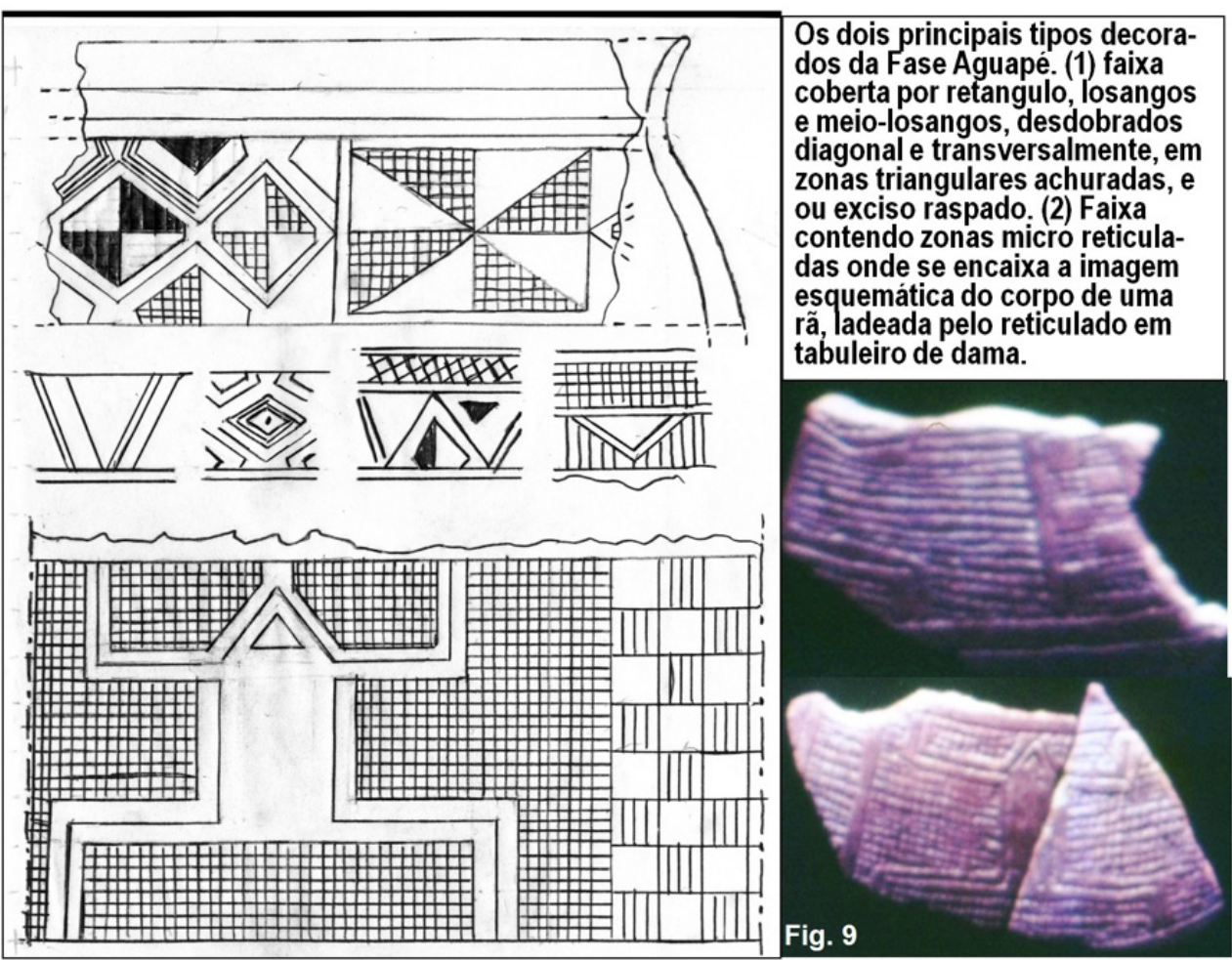


FIGURA 10

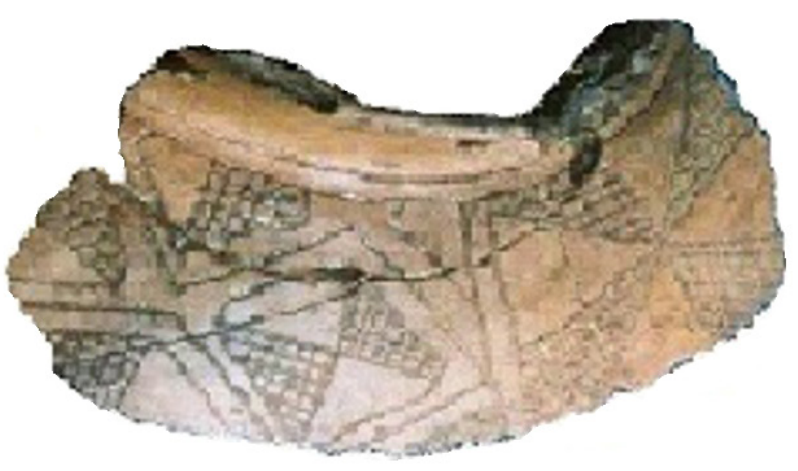

AGUAPÉ

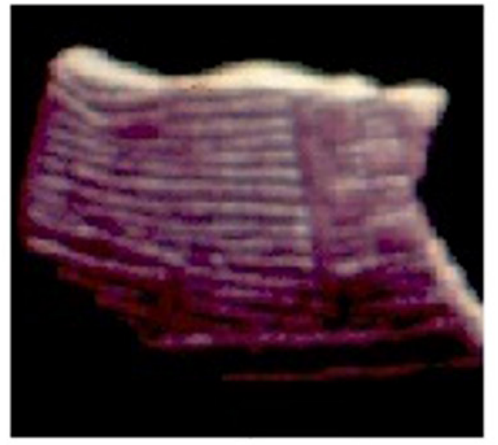

AGUAPÉ

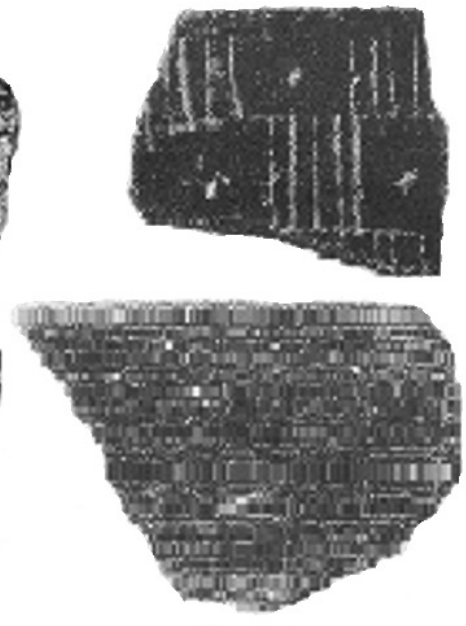

exis)
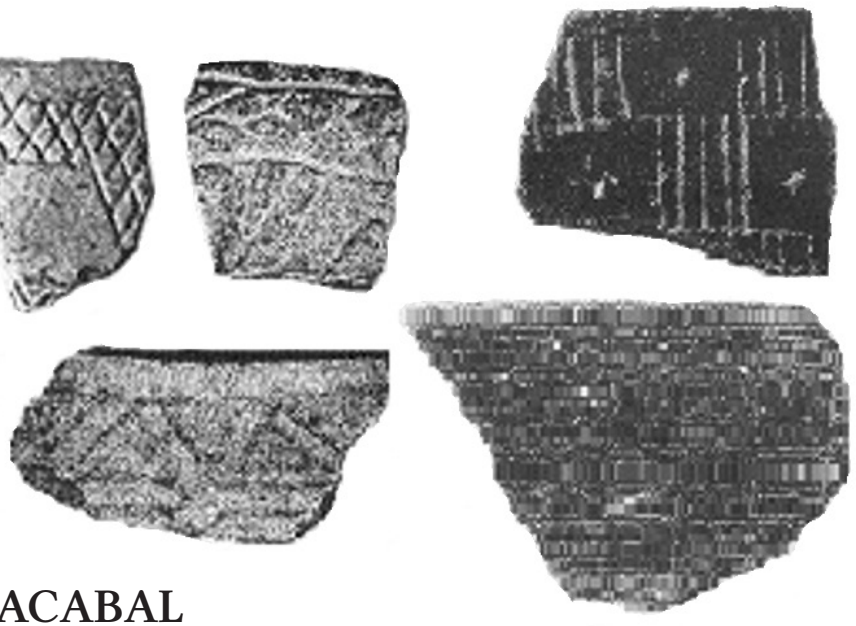

MACHALILLA

\section{BACABAL}

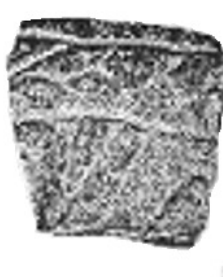

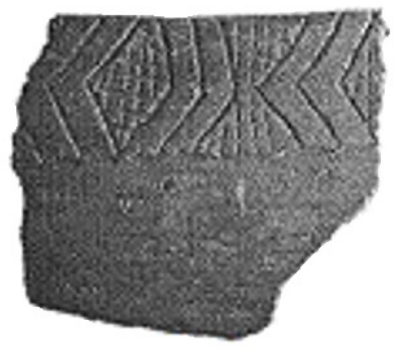

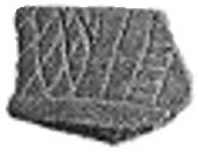

VALDÍVIA

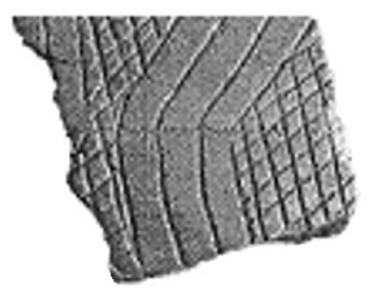


FIGURA 11

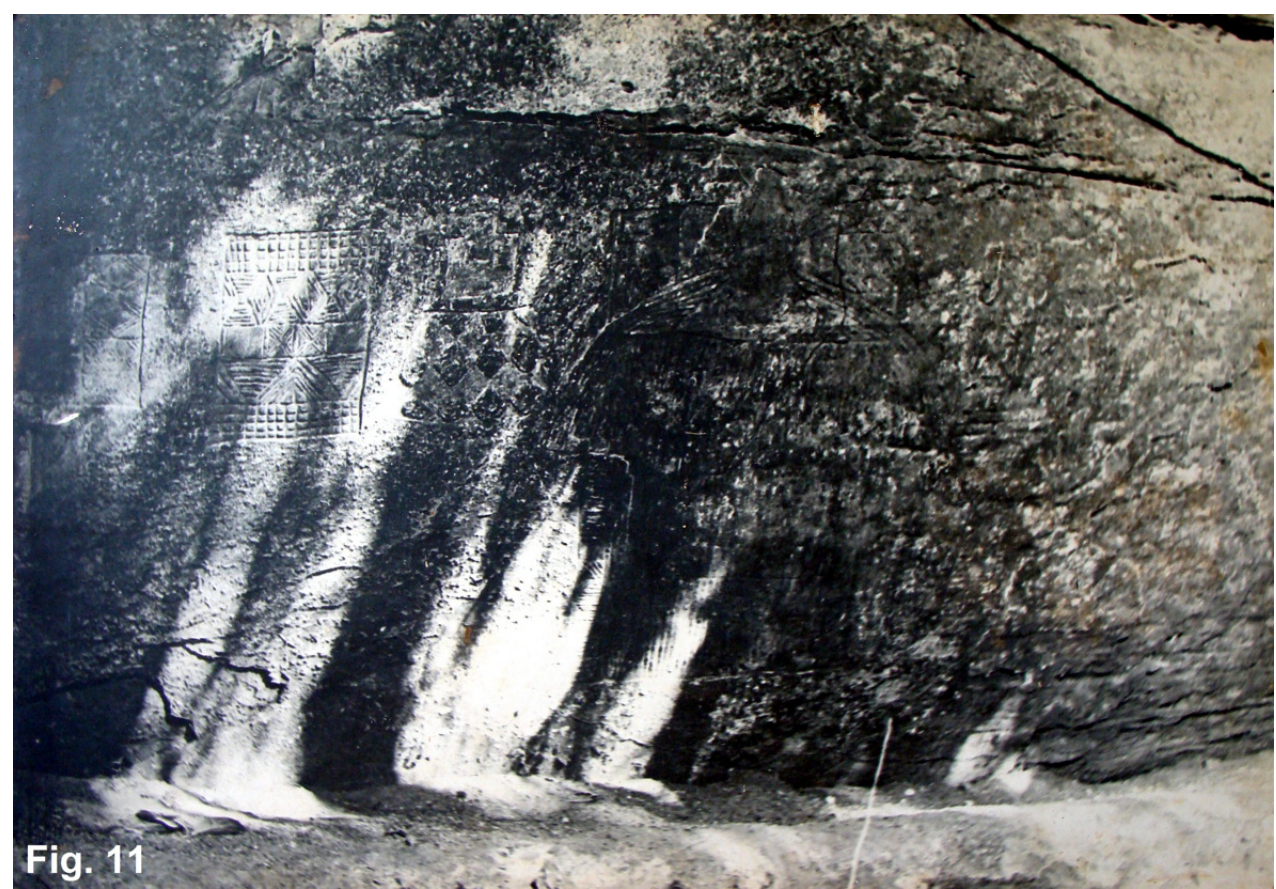

FIGURA 12

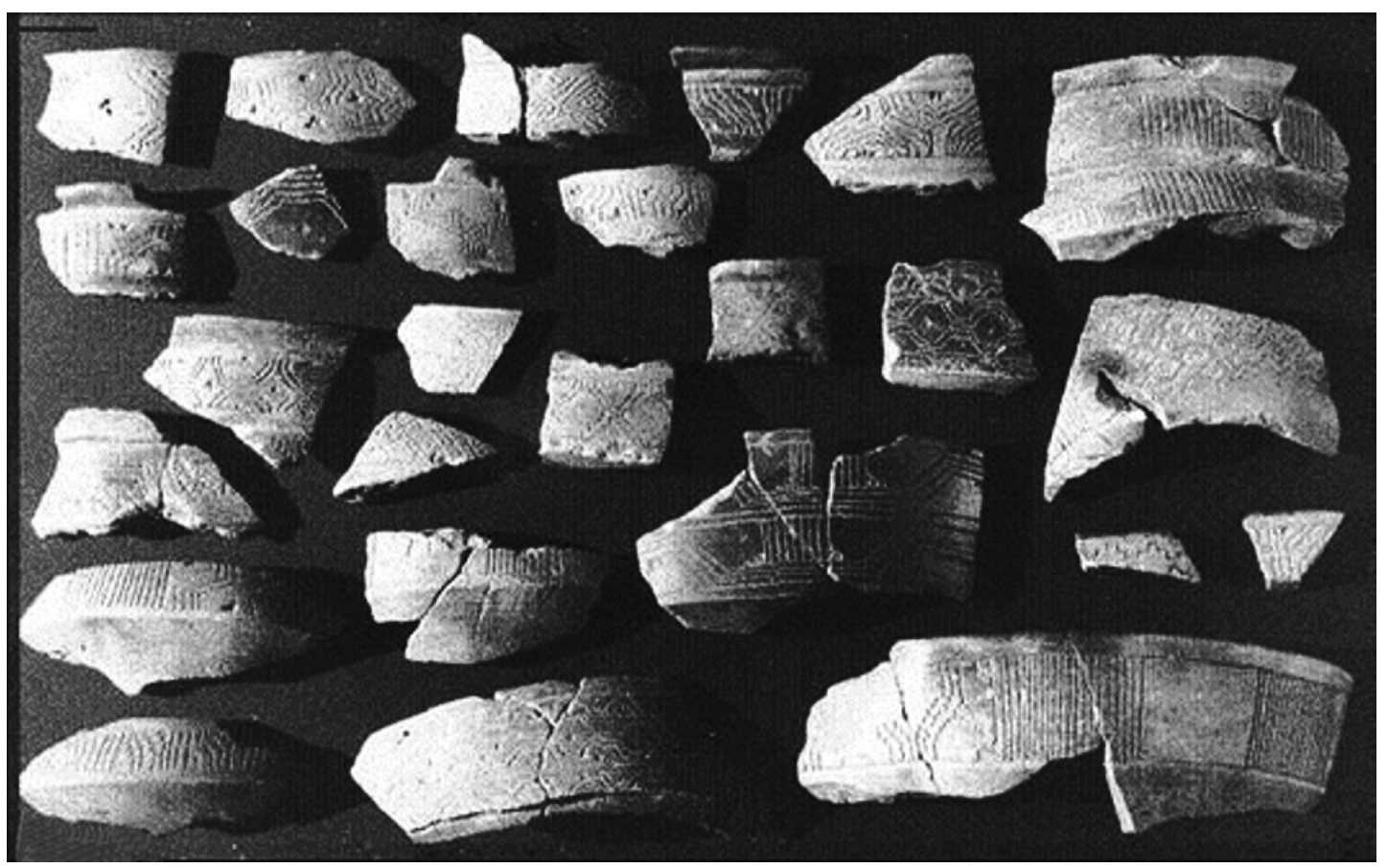


FIGURA 13

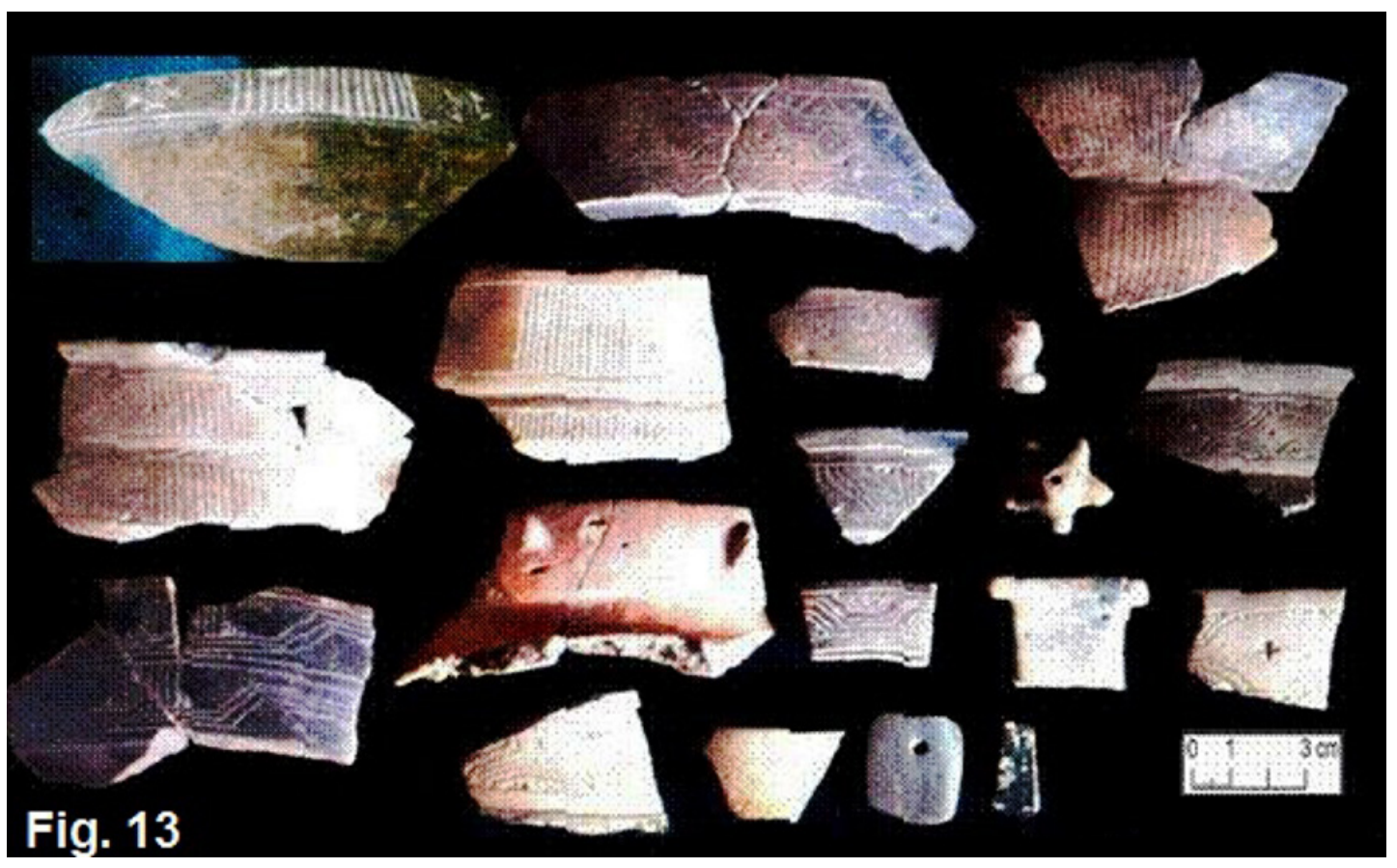

FIGURA 14

VÍNCULOS CULTURAIS TIPOLÓGICOS E TEMÁTICOS
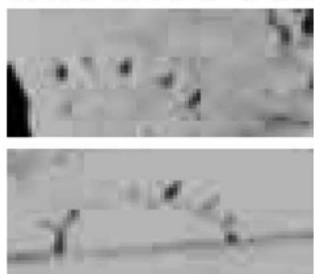

GALERA

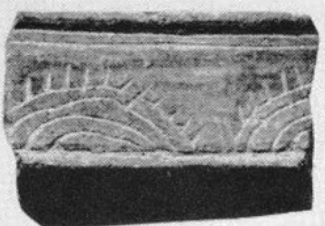

MACHALILLA

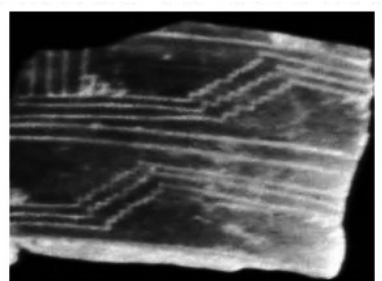

GALERA

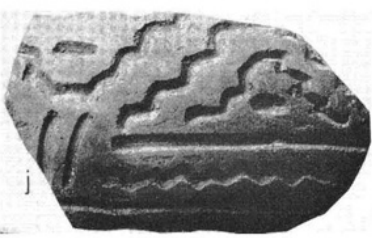

VALDÍVIA

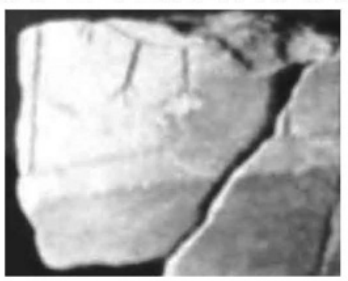

GALERA-AVE

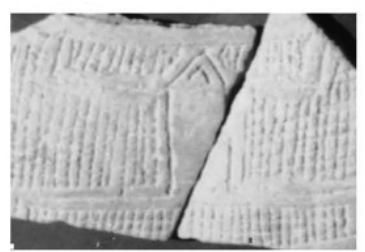

AGUAPÉ-RÃ

VÍNCULO TIPOLÓGICO ENTRE MACHALILLA E GALERA: LINHA TIPO INCISO FINO, MOTIVO EM ARCO RAIADO;

VÍNCULO TIPOLÓGICO ENTRE VALDÍVIA (?) E GALERA: LINHA TIPO INCISO GROSSO, E FINO, MOTIVO ESCALONADO OU ZIGUE-ZAGUE; VÍNCULO TEMÁTICO ENTRE AGUAPÉ E GALERA: ZOOGRAVURAS. 
FIGURA 15

Alguns traços culturais similares entre Jomon, Valdívia (Estrada, Meggers and Evans 1965) e Guatambu, através de alguns tipos Cerâmicos (Miller 1971, Est. 9 e 10; esta Fig. e Fig. 16)

Valdívia;

Jomon;

\section{Guatambu}

1-Est.164, Incised Zigzag h;Honjo,b; Inciso Achurado obliquo, Est. 9 a-c,10 b,h,i;16 a-c.

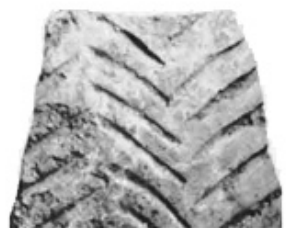

2- Est. 167, Incised Crosshatch, j; Natsushima, e;
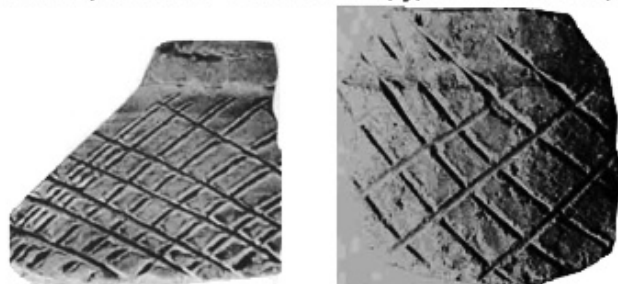

3- Est. 179, Rocker Stamped, f;

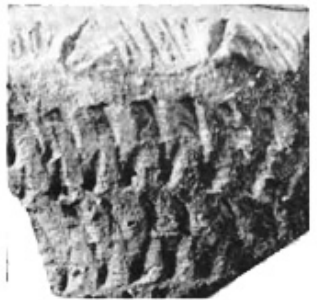

Todoroki, j;

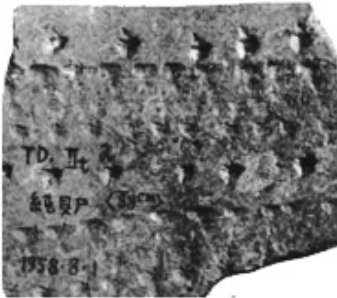

4- Est.170, Drag-and-jab punctate; h, Hajima, a;
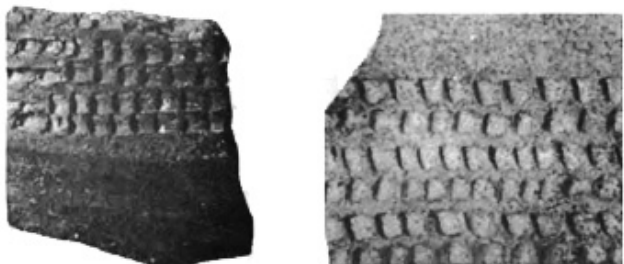

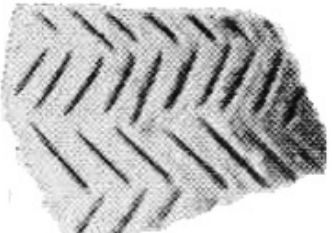

Inciso Cruzado, Est.9, f, g, d, e.

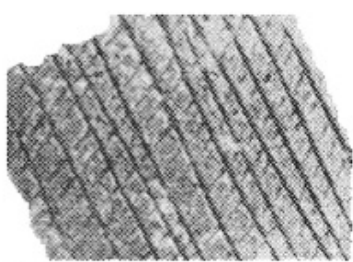

Inciso em Ziguezague, Est. 9, h, i.
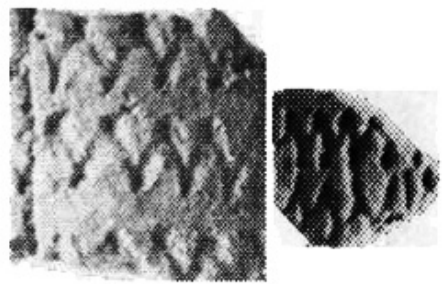

Ponteado arrastado, Est. 9, o.

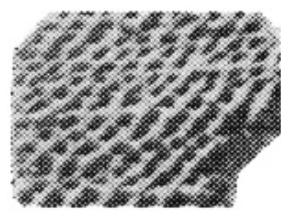

5) Est. 168, Zoned punctuate, I; Natsushima, e; Ponteado zonado, Est. 9, I, n, 10, g, 16, d.
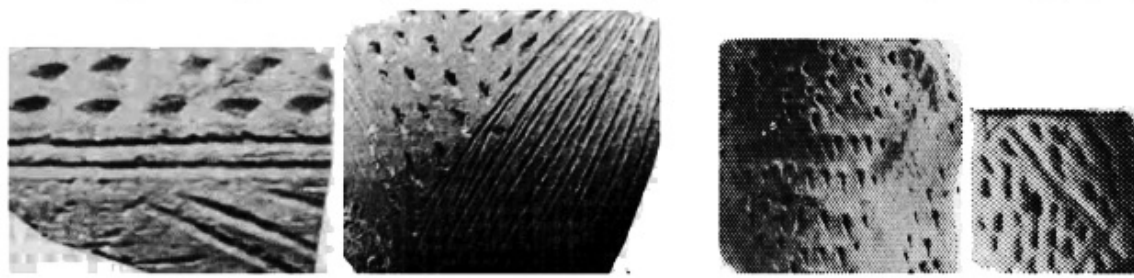
FIGURA 16

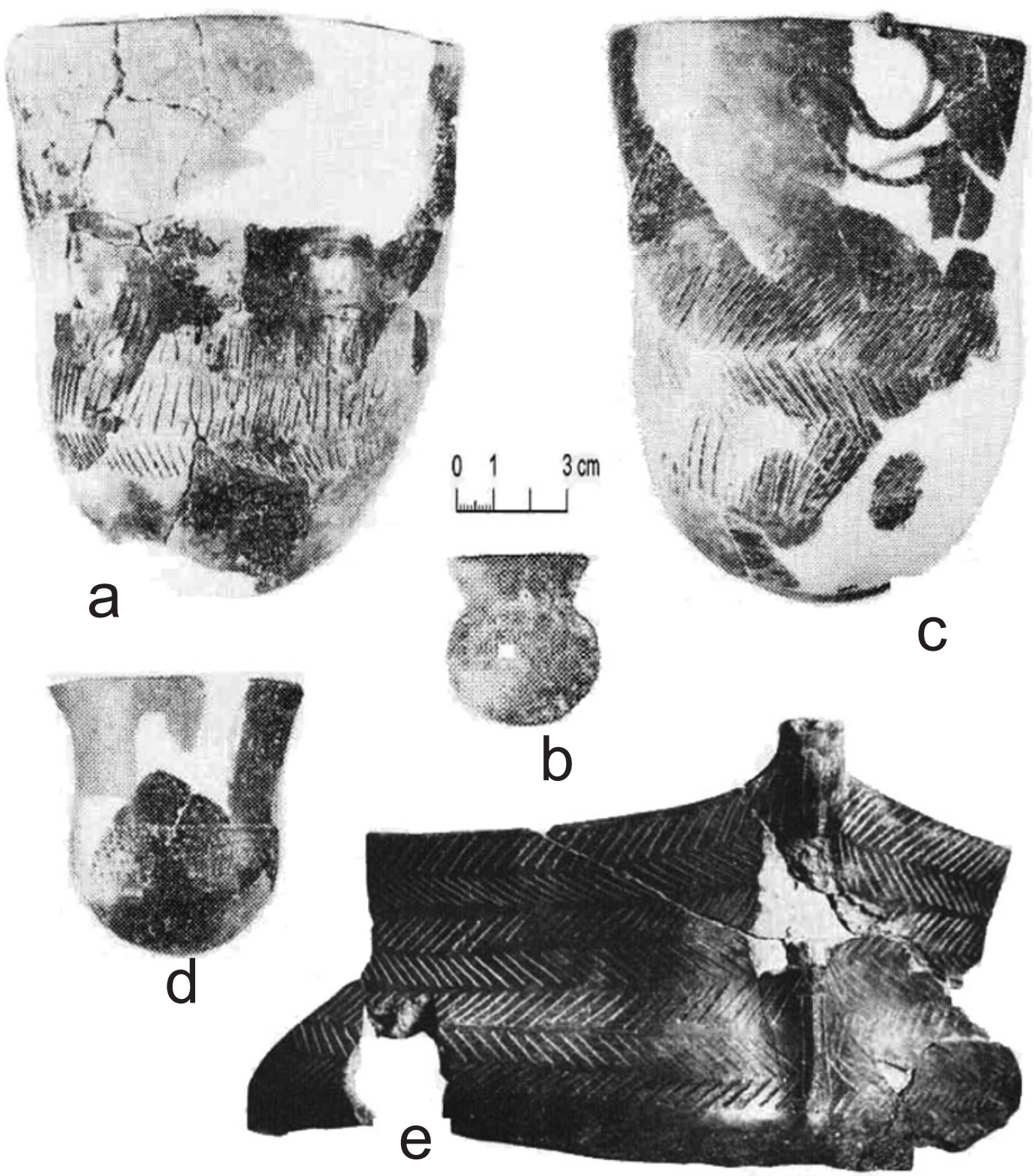

Volume 5, Número 2, Dezembro de 2013373 


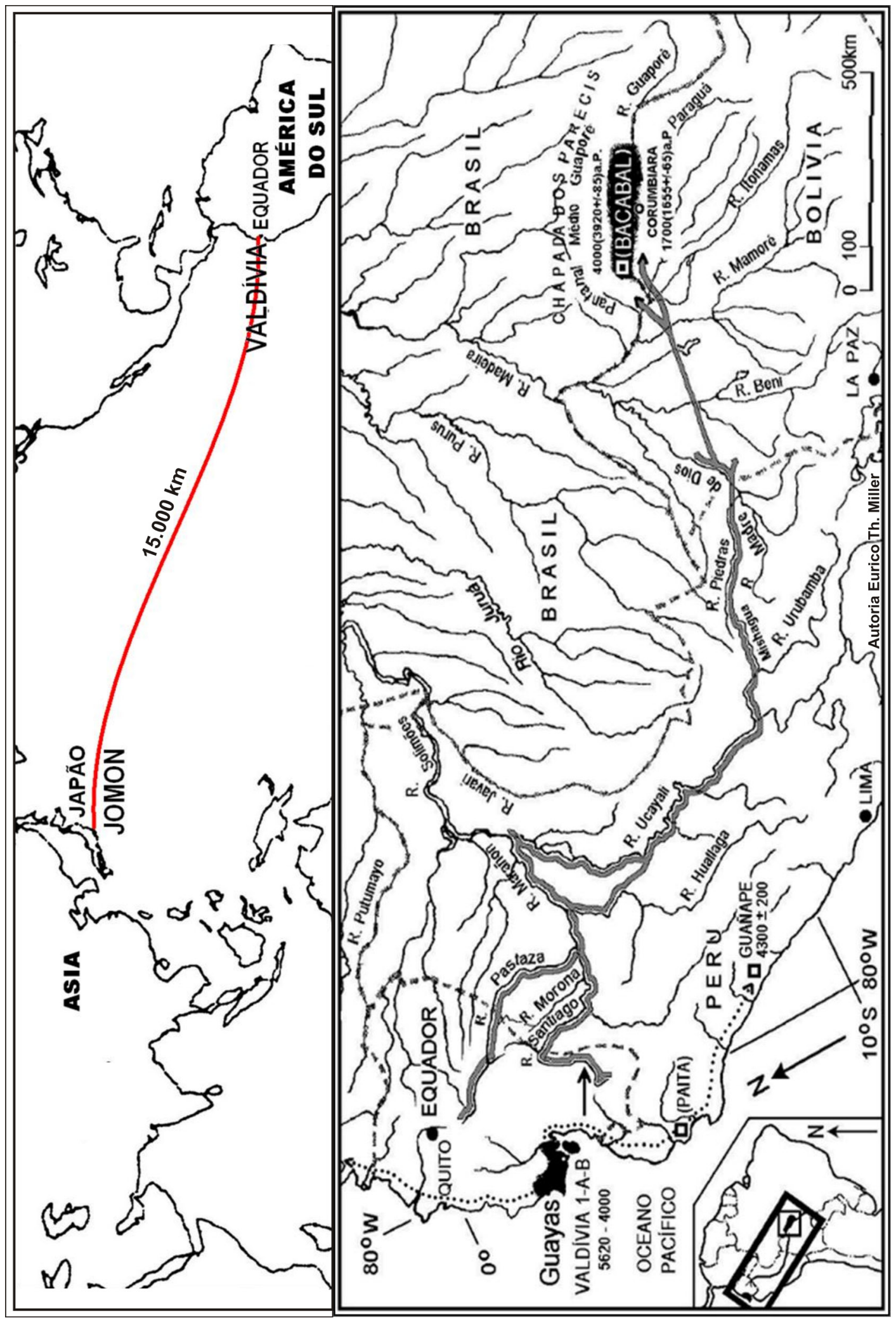

374 Revista Brasileira de Linguística Antropológica 


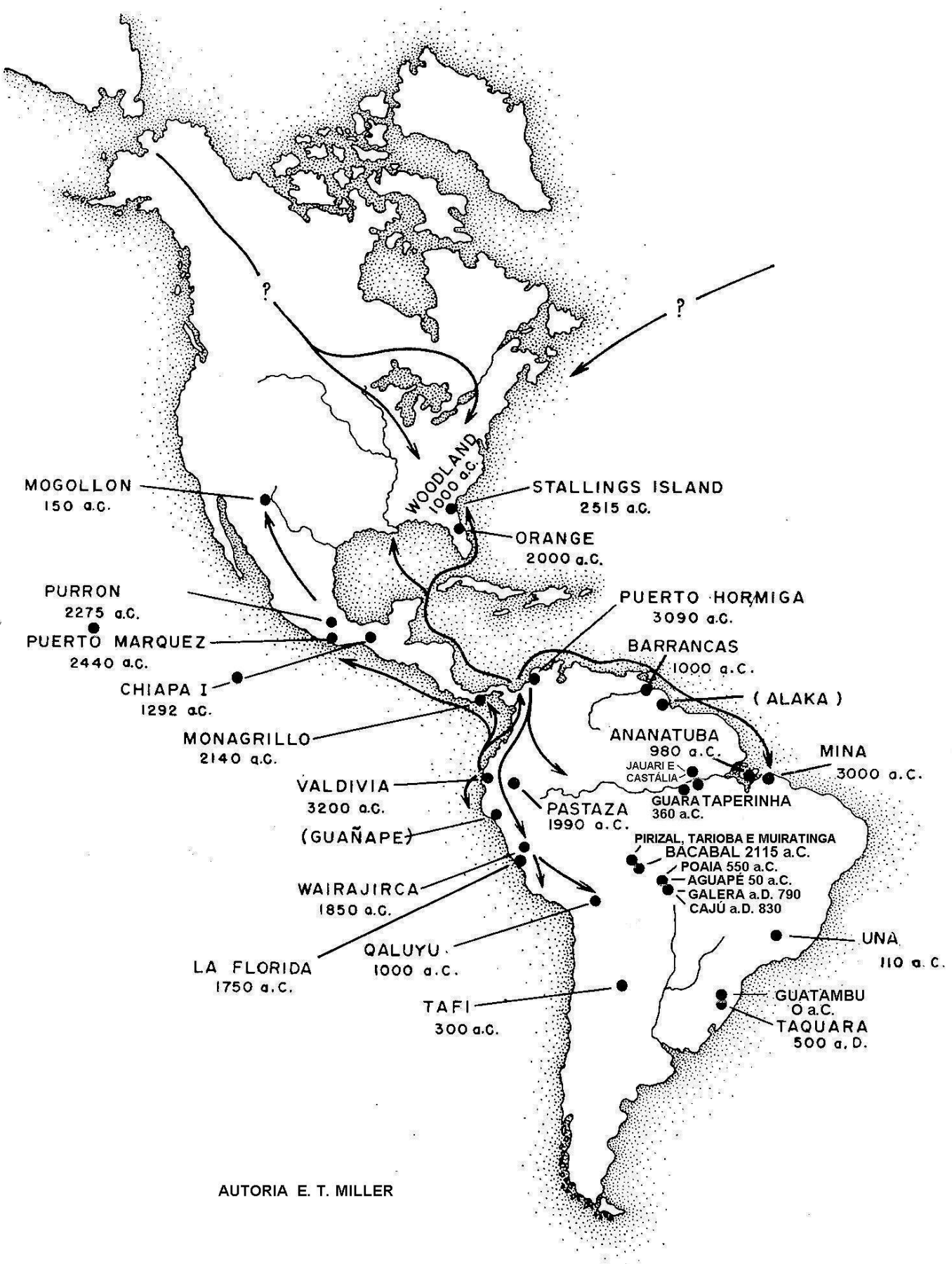




\section{Referências}

Ângulo-Valdéz, Carlos. 1981. La tradición Malambo: um complejo temprano em El NW de Suramérica. Fundación de Investigaciones Nacionales, Banco de La República, Bogotá.

Brochado, José P. et al.. 1969. Arqueologia brasileira em 1968. Um relatório preliminar. Chmyz, Igor (Ed.). 1966. Terminologia arqueológica brasileira para a cerâmica. Parte I. Manuais de Arqueologia 1:1-10. Centro de Estudos e Pesquisas Arqueológicas.

. 1969. Terminologia arqueológica brasileira para a cerâmica. Parte II. Manuais de Arqueologia 2:1-10. Centro de Estudos e Pesquisas Arqueológicas.

1976. Terminologia arqueológica brasileira para a cerâmica (revista e ampliada). Cadernos de Arqueologia 1:119-148.

Coe, Michael, D. 1960. Archeological Linkages with North and South America at La Victória, Guatemala. American Anthropologist 62:363-93. Menasha.

Cruz, Daniel G. da. 2008. Lar, Doce Lar? Arqueologia Tupi na Bacia do Ji-Paraná (RO). Dissertação de Mestrado em Arqueologia. MAE/USP, São Paulo.

Echeverria, José A. (Ed.). 2012. Introducción. In: José A. Echeverria (Ed.). Betty f. Meggers: setenta y cinco años de trayectoria exitosa en la arqueologia sudamericana. Kirugraphics Cia. Ltda, Quito, Equador, pp. 21-84.

Engea. 1991a. Companhia Imobiliária de Brasília, Diretoria Técnica. Estudo de Impacto Ambiental - EIA.

. 1991b. Estudo de Impacto Ambiental - EIA, Zona de Expansão Urbana 1, 2-ZEU-1, RA-II, Gama: Versão definitiva. Brasília.

. 1991c. ENGEA-Relatório de Impacto Ambiental - RIMA, Zona de Expansão Urbana da Cidade Satélite de Brazlândia - Versão definitiva. Brasília.

. 1991d. ENGEA-Relatório de Impacto Ambiental - RIMA, Zona de Expansão

Urbana 1, 2-ZEU-1, RA-II, Gama: Versão definitiva. Brasília. . 1992a. Estudo de Impacto Ambiental - EIA, Setores Habitacionais Recanto das Emas, Catetinho e Ipê, RA-VIII, Núcleo Bandeirante: Versão final. Brasília.

. 1992b. ENGEA - Relatório de Impacto Ambiental - RIMA, Setores Habitacionais Recanto das Emas, Catetinho e Ipê, RA-III, Núcleo Bandeirante: versão final. Brasília.

Estrada, Emilio. 1961. Nuevos Elementos en la Cultura Valdivia: sus Posibles Contactos Transpacificos. Guayaquil, Publicación del Sub-Comite Ecuatoriano de Antropología. 14p. Il.

Estrada, Emilio \& Meggers, Betty J. 1962. Possible Transpacific Pacific Contact on the Coast of Ecuador. Washington, D.C., Science, 135(3501):371-2, Il.

. 1966. Transpacific Origin of Valdivia Phase Pottery on Coastal Ecuador. In: XXXVI Congreso Internacional de Americanistas. España. Actas Y Memorias. Sevilla, V.1,63-7. Il.

Estrada, Emilio, Meggers, Betty J. and Clifford Evans. 1964. The Jambelí Culture of 
South Coastal Ecuador. Smithsonian Institution, U.S. National Museum. Proceedings 115(3492). Washington [S.N.]

Ford, James A. 1957. Método Cuantitativo para Determinar la Cronologia Arqueológica. Instituto de Investigación Etnológica, Universidad del Atlântico. Barranquilla. Divulgaciones Etnológicas 6:09-44. Unión Panamericana, OEA, 122p. Il.

1966. Early Formative Cultures In Georgia and Florida. Salt Lake Sity, American Antiquity 31(6):781-99. Il.

. 1969. A Compararison of Formative Cultures In the Americas. Diffusion or Psychic Unity of Man? Washington, D.C., Smithsonian Contrib. Anthrop. 11. 211p. Il.

Goulding, Michael; Ronaldo Barthem e Efrem Ferreira. 2003. The Smithsonian Atlas of the Amazon. Cartography by Roy Duenas. Smithsonian Books. Washington and London 253p.

Hilbert, Peter P. 1959. Achados Arqueológicos num Sambaqui do Baixo Amazonas. Belém, Museu Goeldi, Inst. Antrop. Etnol.,(10). 22p. Il.

1968. Archaeologische Untersuchungen am mittler Amazonas. In: Beiträge zur vorgeschichte des südamerikanischen Tieflandes. Berlin, Dietrich Reiner, 337 p. il. (Marburger Studien zur Völkerkunde, 1.)

Lima Erig. 2011. A Ocupação pré-colonial na fronteira ocidental: Adaptabilidade humana, territorialidade e aspectos geomorfológicos na microrregião do alto Guaporé, Mato Grosso. Tese de Doutorado. Museu de Arqueologia e Etnologia da Universidade de São Paulo, São Paulo, Brasil.

Machida, Hirochi y Fusão Arai. 1983. Widespread late quaternary tephras in Japan with special reference to archaeology. Quaternary Rechearch 22 (3):133-146.

Marcos, Jorge. G. y Bogomil Obelic. 1998. 14C and TL chronology for the Ecuadorian Formative. El Área Septentrional Andina, pp. 342-359. Quito, AbyaYala.

Meggers, Betty J. 1962. The Machallila Culture: An Early Formative Complex on the Ecuadorian Coast. American Antiquity 28(2):186-192.

. 1964. North and South American Cultural Connections and Convergences. In: jennings, J. \& Norbeck, E., Eds. Pré-Historic Man In The New World, Chicago, Chicago Univ. Press, P.511-26. Il.

1970. Prehistoric New World Cultural Development. History of the Manking: Cultural and Scientific Development. Vol. 3. part 3. UNESCO (Greek Edition). Pp. 5-70. Multilithe.

. 1971. Contacts From Asia. In: ASHE, G. Et Al., Eds., The Quest For America. London. Pall Mall Press, 1971a. P.239-59. Il.

1979. América Pré-Histórica. Tradução de Eliana Teixeira de Carvalho. Paz e Terra, Rio de Janeiro, 1979c. 242p. [Translation of Prehistoric America, 1972] [2nd printing 1985].

. 1980. Did Japanese Fisherman Really Reach Ecuador 5,000 Years Ago? Early Man 2(4):15-9. Il. 
1985a. El Significado de la Difusión como Factor de Evolución. Arica-Chile. Univ. Tarapacá, Chungará, 14:81-90. Il.

1985b. A Utilização de Seqüências Cerâmicas Seriadas para Inferir Comportamento Social IAB. Boletim Série Ensaios 1-48. I1.

1987. El Origen Transpacifico de la Cerámica Valdivia: una Revaluación. Santiago de Chile. Bol. Mus. Chileno de Arte Pre-Colombino 2:9-31. Il.

. 1992. Jomon-Valdivia Similarities: Convergence or Contact? New England Antiquities Research Association. NEARA Journal 27(1/2):22-32, Sum. Il.

. 1992c. Projeto de Investigações Arqueológicas em Sambaquis de Água Doce ao Longo do Baixo Amazonas - Estado do Pará/Brasil. Uma avaliação do potencial crono-arqueológico do sítio PA-ST-27: Cernanbi de Taperinha, e outros nos municípios de Santarém, Alenquer e Monte Alegre. Brasília, 10p. Inédito.

. 1995. Impact of environmental fluctuation on pre-Columbian Amazonian populations. Abstracts, $94^{\text {th }}$ Annual Meeting.

. 1996. Transpacific voyages from Japan to America. Report on visit to Japan sponsored by the John Manjiro-Whitfield Commemorative Center for International Exchange, East Historical Society, and JAOMON Culture Research Group. Kochi Prefecture Cultural Properties Survey Report, 1995: Japonese pp. 106-112; English pp. 131-136. Shimizu city Committee for Education.

. 1997. La Cerâmica Temprana en América del Sur.? Invención Independiente o Difusión? Revista de Arqueologia Americana 13, jul.-dic.

. 1999. El contexto ecológico Del Formativo. In Paulina Ledergerber-Crespo, Ed.,

Formativo sudamericano: una revaluación, pp. 383-393. Abya-Yala.

. 2005. The subversive significance of transpacific contact. NEARA fournal 39:22-29.

2008. Las culturas formatives de la costa del Equador: nuevas perspectives.

Miscelânea Antropológica Equatoriana, Segunda Época 1(1):16-39. Guayaquil.

2010. Review of Handbook of South American Archaeology, edited by Helaine Silverman and William H. Isbell. International fournal of South American Archaeology 7:72-82.

Meggers, Betty J.; Evans, Clifford. 1957. Archeological Investigations at the Mouth of The Amazon. Washington, D.C., Bur. Amer. Ethnol. Bull. 167. 664p, 206 figs. 112 plates, 52 appendix tables.

. 1962. The Machalilla Culture: An Early Formative Complex on the Ecuadorian Coast. American Antiquity 28(2): 186-192. Il. . 1966. A Transpacific Contac in 3000 B.C. Scientific American 214(1):28-35. Jan.

1970. Como Interpretar a Linguagem da Cerâmica: Manual Para Arqueólogos. Washington, D.C., Smithsonian Institution. 111p. Il.

1985. A utilização de sequências cerâmicas seriadas para inferior 
comportamento social. Boletim Série Ensaios 3, Instituto de Arqueologia do Brasileira. Rio de Janeiro.

Meggers, Betty J.; Evans, Clifford; Estrada, Emilio. 1965. Early Formative Period of Coastal Ecuador: the Valdivia and Machalilla Phases. Washington, D.C., Smithsonian Contributions to Anthropology, V.1, 234p. Il.

Miller, Eurico Th. 1961. Pesquisas arqueológicas em campo aberto. "II Encontro de Intelectuais de São Paulo”. São Paulo/SP, 21a26 de agosto de 1961. 38 p., il. (inédito). . 1966. I Semana Arqueológica de Taquara. SEC/DCC/MARSUL - RS/BR e Smithsonian Institution - USA. Taquara/RS, Jun./1966 (Inédito).

. 1967. Pesquisas arqueológicas efetuadas no Nordeste do Rio Grande do Sul. In: PRONAPA. (Programa Nacional de Pesquisas Arqueológicas): Resultados Preliminares do Primeiro Ano, 1965-1966. Publ. Avulsas Mus. Pa. Emílio Goeldi 6:15-38, Il.

1969a. Resultados preliminares das escavações no sítio pré-cerâmico RSLN-1: Cerrito Dalpiaz. Iheringia, Mus. Riogrand. Ciên. Nat., Porto Alegre, Antrop. 1: 43-112, il.

. 1969b. Pesquisas arqueológicas efetuadas no Noroeste do Rio Grande do Sul (Alto Uruguai).

. 1970. As Tradições Taquara e Itararé como uma só Tradição. XXXIX Congresso Internacional de Americanistas. Lima, Perú, 1970. 12 p., Il. (Inédito)

. 1971. Pesquisas arqueológicas efetuadas no Planalto Meridional, Rio Grande Do Sul. Rios Uruguai, Pelotas e das Antas. In: PRONAPA (Programa Nacional De Pesquisas Arqueológicas). Resultados Preliminares do Quarto Ano. 1968-1969. Publ. Avulsas Mus. Pa. Emílio Goeldi, Belém, 15: 37-70.

1974a. Pesquisas arqueológicas efetuadas no Planalto Meridional do Rio Grande do Sul. In: PRONAPA. (Programa Nacional de Pesquisas Arqueológicas): Resultados Preliminares do Quinto Ano, 1969-1970. Publ. Avulsas Mus. Pa. Emílio Goeldi 26:11-24, Il.

. 1974b. Relatório Preliminar Das Pesquisas Arqueológicas Realizadas em Mato Grosso e Rondônia, Programa Paleoindio e Paleoambiente. Taquara, RS, MARSUL \& SI-USA, 1974. 14p. Mapa (Inédito).

1974c. Pesquisas Arqueológicas em Abrigos-Sob-Rocha no Nordeste do Rio Grande do Sul. In: Progr. Nac. de Pesq. Arqueol. Quinto Ano 1969-70. Publ. Avulsas Mus. Pa. Emílio Goeldi, Belém, 26:11-24, Il.

. 1975. Relatório Preliminar Das Pesquisas Arqueológicas Realizadas Em Mato Grosso. PROPPA-Programa Paleoindio e Paleoambiente. Taquara, RS, MARSUL \& SI-USA, 1975. 15p. Mapa (Inédito).

. 1977. Relatório Preliminar Das Pesquisas Arqueológicas Realizadas Em Mato Grosso. Prog. Nac. Pesq. Arqueol. Na Bacia Amazônica. Taquara, RS, MARSUL \& SI-USA, 1977. 16p. Mapa (Inédito). 1978a. Relatório Preliminar Das Pesquisas Arqueológicas Realizadas No 
Território Federal De Rondônia -1978. 10p. Mapa. (Inédito).

1978b. Breve Reconhecimento Arqueológico da "Ilha" Monte Castelo na Fazenda Governamental de Pau d'Oleo, Rondônia. Porto Velho, SEDEAM/ Rondônia. 3p. Il. (Inédito).

1978c. Relatório Preliminar das Pesquisas Arqueológicas Realizadas no

Território Federal de Rondônia. 10 p. Mapa. (Inédito)

1979. Relatório Preliminar das Pesquisas Arqueológicas Realizadas no Sudoeste do Estado do Amazonas - Médio Rio Madeira. 10p. Mapa. (Inédito)

. 1980a. Reconhecimento de Sambaquis Fluviolacustres no Pantanal do Rio Guaporé, Rondônia; Primeiras Prospecções. Porto Velho, SEDEAM/ Rondônia. 6p. Il.(Inédito).

. 1980b. Relatório Preliminar das Pesquisas Arqueológicas Realizadas nos Rios Madeira, Mamoré e Guaporé. Mapa. (Inédito)

. 1983a. História da Cultura Indígena do Alto Médio-Guaporé (Rondônia e Mato Grosso). Porto Alegre, Pontifícia Univ. Católica do RGS, Mestrado - História da Cultura.

1983b. Pesquisas Arqueológicas em Sambaquis Fluviolacustres no Noroeste do Pantanal do Rio Guaporé, Rondônia. Porto Velho, Relatório SECET/Rondônia, 15p. Il.(Inédito).

- 1985a. Os Sítios Arqueológicos em Rondônia e Sudoeste da Amazônia Brasileira. In: Compêndio de História e Cultura de Rondônia. Fund. Cult. Est. Rondônia - FUNCER Relat. Encon. Est. Rest. Preserv. Patrim. Hist. de Rondônia. Porto Velho, SECET/Rondônia, 10p. Il.

. 1985b. Faixa Cronoarqueológica do Sudoeste Amazônico e Culturas nela Inseridas até o Presente. In: III Reunião Científica da SAB. Goiânia-Goiás, Set. 16p., Il. (Inédito).

. 1986a. A Ocupação Humana Pré-Histórica do Pantanal do Guaporé. Anais. V Encontro de Pesquisadores da Amazônia. Universidade Federal do Amazonas, Manaus.

. 1986b. As Fases Sinimbu e Bacabal (em Sambaquis do Pantanal do Guaporé). Relatório, Smithsonian Institution - USA. 9 P., Il. (Inédito)

. 1986c. A SECET e o Meio Ambiente. XI Forum Nacional de Secretário de Cultura. Salvador, Bahia, Maio. 3p.

. 1987a. Projeto de Avaliação do Potencial Arqueológico na Área de Influência da Rodovia BR-429 - Presidente Médici/Costa Marques, Rondônia, 1986. Relat. GERO/ SEPLAN, Porto Velho-Rondônia/Brasil,. 26p. Il.

. 1987b Projeto de Avaliação do Potencial Arqueológico na Área de Abrangência da UHE Ji-Paraná, 1986, Nota Prévia. Relatório Eletronorte - CNEC, Brasília - São Paulo. 63p., 14 Fig. 15 Est. (Inédito).

. 1987c. Inventário arqueológico da bacia e sub-bacias do rio Madeira, 1974 1987. Relatório, Eletronorte - CNEC, Brasília - São Paulo. 55 p., mapa. 
1987d. Relatório Preliminar das Pesquisas Arqueológicas Realizadas na Área da Usina Hidroelétrica de Samuel, (25-05 a 30-11/1987). Projeto Arqueológico UHE Samuel. Salvamento, Rio Jamarí, Rondônia, Brasil. Governo de Rondônia/SECET Eletronorte, Porto Velho - Brasília. 25 P. Mapa, 4 Fig. (Inédito).

1992c. Adaptação Agrícola Pré-Histórica no Alto Rio Madeira. In: Meggers, B.J., Ed., Prehistoria Sudamericana; Nuevas Perspectivas. Segundo Simposio Conmemorando el Quinto Centenario, National Museum of Natural History, Smithsonian Institution, Washington, D.C., Oct. 1988. Chile, Ed. Universitaria, P.219-229. Il. Taraxacum.

1994. Avaliação do Potencial Arqueológico da UHE Guaporé, MT. Relatório encaminhado à CEMA-Consultoria em Meio Ambiente. Brasília. 1994 (Inédito).

1999. A Limitação Ambiental como Barreira à Transposição do Período Formativo no Brasil. In: Paulina Ledergerber-Crespo, Ed., Formativo sudamericano; uma revaluación, pp. 331-339. Abya Yala, Quito.

2007. Seqüências seriadas quantitativas aplicadas às Culturas, Cerâmicas e Pré-cerâmicas Arqueológicas, e Interpretações de seus Resultados sob Efeitos do Meio Ambiente. In: I Seminário de Arqueologia de Sul - Americanistas na Amazônia Ocidental. De 25 a 26 de outubro de 2007, Universidade Federal de Rondônia - UNIR (Inédito).

2009a. Pesquisas Arqueológicas no Pantanal do Guaporé-RO, Brasil: a Seqüência Seriada da Cerâmica da Fase Bacabal. In: Meggers B.J. Org., Arqueologia Interpretativa. O Método Quantitativo para o Estabelecimento de Sequências Cerâmicas: Estudo de caso. 2002. Marcos A. C. Zimmermann et al. Porto Nacioanl, UNITINS. Pp.103-17. Il.

2009b. "A cultura cerâmica do Tronco Tupí no alto Ji-Paraná, Rondônia Brasil”. Revista Brasileira de Linguística Antropológica 1(1): 35-136.

et al. Orgs. 1992a. In: Eletronorte. Arqueologia nos Empreendimentos Hidrelétricos da Eletronorte; Resultados Preliminares, Brasília.

1992b. As Fases Pré-Cerâmicas Itapipoca, Pacatuba e Massangana Agrícola. In: Arqueologia nos Empreendimentos Hidrelétricos da Eletronorte; Resultados Preliminares. Eurico Th. Miller et al. (Orgs.). Centrais Elétricas do Norte do Brasil S.A. Brasília - DF. P. 32-38, Il.3

Miranda, F. M. 1964. Os aborígenes da América do Sul. In: História das Américas. 5.ed. Rio de Janeiro, Ed. Brasiliana, 2:400p., 1964. Il.

Missão Rondon. 2003. Apontamentos sobre os trabalhos realizados pela Comissão de Linhas Telegráficas Estratégicas de Mato Grosso ao Amazonas / sob a direção do Coronel de Engenharia Cândido Mariano da Silva Rondon, de 1907 a 1915. Brasília: Senado Federal, 284 p. (Edições do Senado Federal; 8)

Muñoz, Cristina. Betty J. Meggers y Clifford Evans en la Arqueologia Ecuatoriana. In: Echeverria, José A. (Ed.). Betty J. Meggers: setenta y cinco años de trayectoria exitosa en la arqueologia sudamericana. Kirugraphics Cia. Ltda, Quito, Equador. 2012. pp. 139-147. Il. 
Oyuela-Caycedo, Augusto y Renée M. Bonzani. 2005. San Jacinto 1: a historical ecological approach to an archaic site in Colômbia. Tuscaloosa, University of Alabama Press.

PRONAPA, Resultados Prelininares do $3^{\circ}$ ano, 1967-1968. Publ. Avul. Mus. Pa. Emílio Goeldi, Belém, 12. 33p. il. 1969.

Puttkamer, Jesco Von. 1979. Man in the Amazon: Stone Age Present Meets Stone Age Past. National Geographic 155(1):60-83.

Rodrigues, Arion D. 1958. Classification of Tupi-Guaraní. Int. J. Am. Ling., Blomington, Indiana U.S.A. 24:231-234.

. 1964. A classificação lingüística do tronco Tupi. Revista de Antropologia, 12 (1-2):99-104.

1986. Línguas Brasileiras. Para o conhecimento das línguas indígenas. São Paulo: Loyola.

1988. Proto-Tupi evidence for agriculture. Trabalho apresentado na 1st International Ethnogiology Conference. Belém.

Reichel-Dolmatoff G. 1965. "Excavaciones arqueológicas en Puerto Hormiga" (Departamento de Bolívar) Antropologia 2, BOGOTA, Ediciones de la Universidad de los Andes.

1972.'The Cultural Context of Early Fiber-Tempered Poterry in Northern Colombia”, Anthropological Society Pubs, 6:1-8, Florida.

1985. Monsú. Un sítio arqueológico, Bogotá, Biblioteca Banco Popular.

Raymond, Scott; Augusto Oyuela-Caicedo, and Patrick H. Carmichael. 1998. The Earliest Ceramic Technologies of the Northern Andes: A Comparative Analysis. MASCA Research Papers in Science and Archaeology, Supplement to vol. 15 (Fig. 8).

Roosevelt, Anna C., R.A. Housley, M. Imazio da Silveira, S. Maranca y R. Johnson. 1991."Eighth Millennium Pottery From A Prehistoric Shell Midden in the Brazilian Amazon”, Science 254:1621-1624.

Roosevelt, Anna C., 1995. "Early pottery in the Amazon: Twenty years of scholarly Obscurity, The Emergence of Pottery, William K. Barnett y John W. Hoopes, eds.,pp.115-131. Washington DC, Smithsonian Institution Press.

Roosevelt, Ana C. et al. 1996. Paleoindian Cave Dwejjers in the Amazon: The Peopling of the Americas. Science 272:373-384.

Simões, Mário F., 1972. Índice das fases arqueológicas brasileiras. 1950-1971. Publ. Avulsas Mus. Pa. Emílio Goeldi 18:14-16, 18, 19, 22-24, 26, 34-36, 39-41, 46, 47, 52, 53, 56-60, 69, 72. il. Belém.

1981. Coletores-pescadores ceramistas do litoral do Salgado (Pará). Nota preliminar. Boletim do Museu Paraense Emílio Goeldi, Nova Série: Antropologia, 78: 1-26, il. Belém.

Simões, Mario F. e Araujo-Costa, F. 1978. Áreas da Amazônia Legal Brasileira para pesquisa e cadastro de sítios arqueológicos. Belém, Museu Paraense Emílio Goeldi, Publicações Avulsas, n. 30. 
. 1983. Pesquisa e cadastro de sítios arqueológicos na Amazônia Legal Brasileira. 1978-1982. Belém, Museu Paraense Emílio Goeldi (Publ. Avulsas, 38). p. 15, (34-38, 62-78, 85-87, 96.)

Suguio, Kenitiro. 1999. Geologia do Quaternário e mudanças ambientais. São Paulo: (passado+presente=futuro?) Paulo’s Comunicação e Artes Gráficas.

Zimpel Neto Carlos A. 2009. Na direção das periferias extremas da Amazônia: arqueologia na bacia do rio Jiparana, Rondônia. Dissertação de Mestrado em Arqueologia. MAE/USP, São Paulo.

Data recebimento: 04/12/2012

Data aceite: 15/08/2013 